August $2004 \quad$ • NREL/SR-500-34961

\title{
A Preliminary Assessment of Potential Avian Interactions at Four Proposed Wind Energy Facilities on Vandenberg Air Force Base, California
}

\section{Period of Performance: November 2001 - May 2002}

BioResource Consultants Ojai, California 


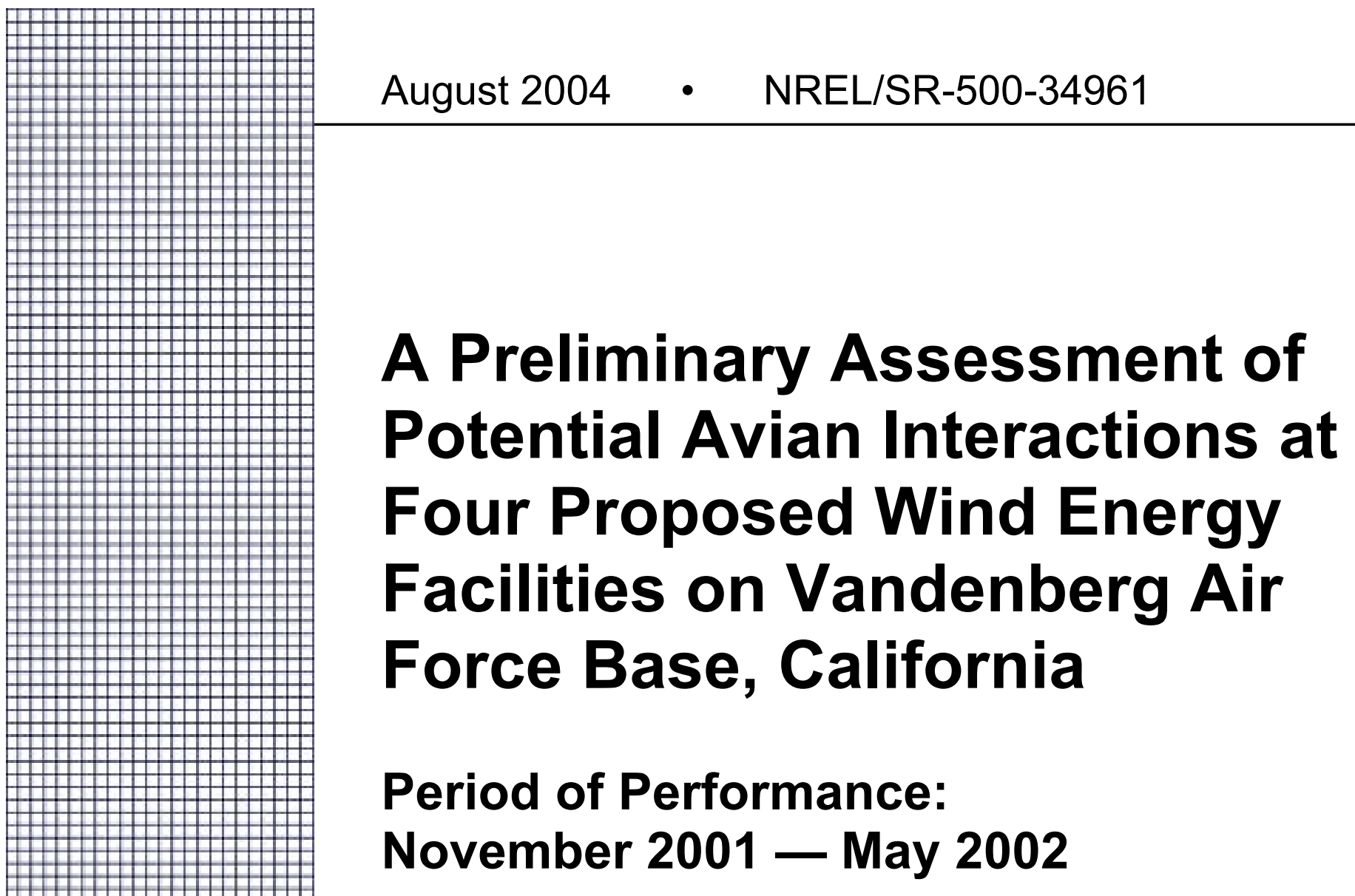

BioResource Consultants

Ojai, California

NREL Technical Monitor: K. Sinclair

Prepared under Subcontract No. LAT-1-31237-01

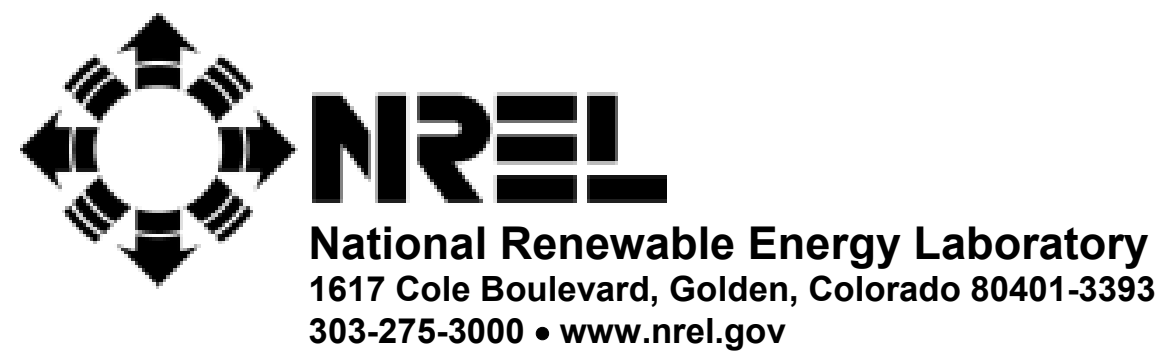

Operated for the U.S. Department of Energy

Office of Energy Efficiency and Renewable Energy

by Midwest Research Institute • Battelle

Contract No. DE-AC36-99-G010337 


\section{NOTICE}

This report was prepared as an account of work sponsored by an agency of the United States government. Neither the United States government nor any agency thereof, nor any of their employees, makes any warranty, express or implied, or assumes any legal liability or responsibility for the accuracy, completeness, or usefulness of any information, apparatus, product, or process disclosed, or represents that its use would not infringe privately owned rights. Reference herein to any specific commercial product, process, or service by trade name, trademark, manufacturer, or otherwise does not necessarily constitute or imply its endorsement, recommendation, or favoring by the United States government or any agency thereof. The views and opinions of authors expressed herein do not necessarily state or reflect those of the United States government or any agency thereof.

Available electronically at http://www.osti.gov/bridge

Available for a processing fee to U.S. Department of Energy and its contractors, in paper, from:

U.S. Department of Energy

Office of Scientific and Technical Information

P.O. Box 62

Oak Ridge, TN 37831-0062

phone: 865.576 .8401

fax: 865.576 .5728

email: mailto:reports@adonis.osti.gov

Available for sale to the public, in paper, from:

U.S. Department of Commerce

National Technical Information Service

5285 Port Royal Road

Springfield, VA 22161

phone: 800.553 .6847

fax: 703.605.6900

email: orders@ntis.fedworld.gov

online ordering: http://www.ntis.gov/ordering.htm 
TABLE OF CONTENTS

DEFINITIONS

IV

1.0 INTRODUCTION

$\begin{array}{lr}2.0 \text { PROJECT AREA } & 2\end{array}$

$\begin{array}{lr}2.1 \text { General Features } & 2\end{array}$

$\begin{array}{lr}\text { 2.2 Proposed Wind Turbine Sites } & 3\end{array}$

$\begin{array}{ll}3.0 \text { METHODS } & 3\end{array}$

$\begin{array}{ll}\text { 4.0 RESULTS } & 5\end{array}$

4.1 General Bird Use: Results of 60-Minute, 200-m Radius Surveys 5

$\begin{array}{ll}\text { 4.2 Raptor Activity: Results of Raptor Surveys } & 6\end{array}$

$\begin{array}{lr}\text { 4.3 Bats } & 6\end{array}$

$\begin{array}{lr}\text { 4.4 Other Sensitive Resources } & 8\end{array}$

$\begin{array}{ll}\text { 5.0 DISCUSSION AND RECOMMENDATIONS } & 10\end{array}$

$\begin{array}{ll}\text { 6.0 ACKNOWLEDGMENTS } & 12\end{array}$

$\begin{array}{ll}\text { 7.0 REFERENCES } & 13\end{array}$

APPENDIX A: BIRD OCCURRENCE AT THE WATERFOWL NATURAL RESOURCE AREA, VANDENBERG AFB

APPENDIX B1: RESULTS OF 2001 SANTA MARIA AUDUBON SOCIETY BIRD COUNT CONDUCTED ON VAFB (SOURCE: NATIONAL AUDUBON SOCIETY 2001)

APPENDIX B2: RESULTS OF 2001 LA PURISIMA AUDUBON SOCIETY BIRD COUNT CONDUCTED ON VAFB (SOURCE: LA PURISIMA AUDUBON SOCIETY 2002) 


\section{Definitions}

CNDDB: California Natural Diversity Data Base MSL: Mean Sea Level

NREL: National Renewable Energy Laboratory

NWCC: National Wind Coordinating Committee

VAFB: Vandenberg Air Force Base

USAF: United States Air Force

WRA: Wind Resource Area 


\subsection{Introduction}

The United States Air Force (USAF) is investigating whether to install wind turbines to provide a supplemental source of electricity at Vandenberg Air Force Base (VAFB) near Lompoc, California. As part of that investigation, VAFB sought assistance from the U.S. Department of Energy's National Renewable Energy Laboratory (NREL) to provide a preliminary characterization of the potential risk to wildlife resources (mainly birds and bats) from wind turbine installations.

Although wind shows great promise as an efficient, environmentally benign renewable energy source, the installation of turbines and their required infrastructure can result in adverse impacts to wildlife and their habitat. These impacts and their significance on local wildlife populations vary greatly from site to site (AWEA 1995; Erickson et al. 2001).

With wind power development expanding throughout North America and Europe, concerns have surfaced over the number of bird fatalities associated with wind turbines (Morrison 1996; Morrison and Sinclair 1997). Guidelines developed for the wind industry by the National Wind Coordinating Committee (NWCC) recommend assessing potential impacts to birds, bats, and other potentially sensitive resources before construction (Anderson et al. 1999). The primary purpose of an assessment is to identify potential conflicts with sensitive resources, to assist developers with identifying their permitting needs, and to develop strategies to avoid impacts or to mitigate their effects.

This report provides a preliminary (Phase I) biological assessment of potential impacts to birds and bats that might result from construction and operation of the proposed wind energy facilities on VAFB.

The specific objectives of the project were to

1- Review available information and conduct a general site evaluation to characterize bird and bat resources at or near the proposed facilities

2- Conduct preliminary field surveys to record bird species occurrence, relative abundance, and bird use at each of the sites

3- Based on the preliminary findings resulting from Objectives 1 and 2 (above), assess the likelihood and extent of risk to birds and bats that might result from the proposed project

4- Recommend whether additional studies, such as detailed site evaluations, pre-construction surveys, and/or post-construction monitoring are needed.

The scope of the project was limited because of funding constraints. BioResource Consultants (BRC) was initially funded to address these objectives at one proposed wind turbine location on VAFB. Because the Air Force changed the design of the wind energy project, we were asked to include in our study five potential areas located throughout VAFB. This request was later amended to a final selection of four potential sites on VAFB, with a single wind turbine installation per site.

The funding for this project was not increased, so the level of effort originally proposed for one site was distributed equally over four study sites. This resulted in a smaller sampling effort per site and a reduction in the field studies period. 
The study results would have benefited from a more robust sampling effort (i.e., three to four visits per site per month over a 12-month period). In addition, the study design could have been improved if a turbine/tower hardware configuration had been selected and if the location(s) where the turbines were to be installed had been selected prior to our conducting the field surveys. With this information, we could have addressed species occurrence and relative abundance within a zone of risk. This would have facilitated a more complete analysis of the potential impacts of turbine installation and operation at each proposed site.

\subsection{Project Area}

\subsection{General Features}

Vandenberg Air Force Base (Figure 1) is located approximately 55 miles $(88 \mathrm{~km})$ north of Santa Barbara, California. Situated along a 35-mile stretch of undeveloped coastline, the base extends inland from 2 to 13 miles and encompasses a total of 99,492 acres $\left(\sim 150 \mathrm{mi}^{2}\right)$.

A substantial wind resource exists on VAFB, mainly because of its location along a stretch of coastline that is at the confluence of two major ocean currents. It is here at Point Conception that the northern California (moist/cool) climate diverges from the southern California (dry/warm) climate. Given the maritime influence, VAFB's climate is relatively mild and typical of the Mediterranean climate that occurs throughout this portion of California. Wet and cool conditions prevail from November through April, with dry and warm conditions present for the rest of the year. The average annual precipitation ranges from 11 to 13 inches. The higher elevations can receive as much as 20 inches of rain per year. Night and morning low cloudiness and fog persist during much of the summer.

Because the base is situated in this transition zone, several plant and animal species that occur there are at northern or southern limits of their ranges (Coulombe and Cooper 1976; in Pierson et al. 2002).

VAFB's surface topography is varied, with the highest relief occurring on the southern half. Three prominent ridges cross VAFB: Casmalia Hills, Purisima Hills, and Santa Ynez Mountains. The Casmalia Hills rise to 1,650 feet in the northwest corner of the base. The highest point is 2,159 feet at Tranquillion Mountain on the southern portion of the base.

VAFB is effectively divided into the northern and southern halves by the Santa Ynez River. Most of the developed areas of the base are in the Cantonment area on the northern half. The base is primarily a missile launching facility, so large portions of it remain relatively undisturbed for long periods by base operations. About $80 \%$ of the base supports vegetation in a relatively natural state, relatively few VAFB personnel are present, and vehicular and human disturbance is relatively low. These factors help to provide high-integrity wildlife habitat in many areas.

Ferren et al. (1999) provided a comprehensive classification system for the upland and wetland plant communities found on VAFB. The vegetation types found on VAFB include wetlands (i.e., freshwater marsh and coastal salt marsh), box elder and willow-riparian woodlands, coastal beaches, coastal dunes, rocky shoreline, Burton Mesa chaparral, coastal sage scrub, coastal bluff scrub, dune scrub, cismontane-introduced grassland, coast live oak woodland, tanbark oak woodland, and Bishop pine forest. 
Several active wildlife management programs are underway on VAFB. The base is a major breeding location for California least terns and snowy plovers, which require nesting habitat protection programs and predator control efforts. Also, the base cooperates with La Purisima Audubon Society on the development and maintenance of a system of ponds. These are designated as the Waterfowl Natural Resource Area. These wetlands and their associated riparian vegetation attract a wide variety of birds and other wildlife (Appendix A).

\subsection{Proposed Wind Turbine Sites}

VAFB initially identified five potential areas where single wind turbines might be installed. Each would be capable of generating about 1 megawatt of electrical energy. Before the field studies began, Site 2 was eliminated from consideration, leaving Sites 1, 3, 4, and 5 to be included in the assessment (Figure 1; Figures 2a-d).

When the study began, the type of turbines, the support structures for the turbines, and the turbine blade designs to be used were unspecified, as were the exact locations where they would be installed. For each study site, we determined an approximate center point at which a turbine might be installed and included in our surveys a circular area of generally flat terrain (approximately 200-m radius) around that point. It was assumed that somewhere within those general site boundaries, a single turbine of unspecified tower height and rotor diameter would likely be installed.

The four study sites are:

Site 1 (Orion Road) is a disturbed area surrounded by central coastal scrub dominated by coyote bush (Baccharis pillularis), with smaller patches of California sagebrush (Artemisia californica), bush monkey flower (Mimulus aurantiacus), black sage (Salvia mellifera), and scattered scrub oak (Quercus dumosa). A small freshwater marsh is located south of the site. The elevation at Site 1 is 1,768 feet above mean sea level (MSL).

Site 3 (El Rancho Road) is vegetated entirely by central coastal scrub dominated by coyote bush with patches of California sagebrush, bush monkey flower, and black sage. A large grove of gum (Eucalyptus) is located east of the site. The elevation at Site 3 is 287 feet above MSL.

Site 4 (Arguello Road) is immediately east of the intersection of Arguello Road and Santa Ynez Road. An existing communications structure (\# 460) with associated tower and guy wires is located onsite. The site is surrounded by iceplant (Carpobrotus sp.), which is surrounded by central coastal scrub. A grove of pines is located just north of the site. The elevation at Site 4 is 1,397 feet above MSL.

Site 5 (Honda Ridge Road) includes two towers with guy wires (structures \# 188 and \# 189). The site is surrounded by relatively undisturbed central coastal scrub. A grove of pines is located north of the site. The elevation at Site 5 is 1,539 feet above MSL.

\subsection{Methods}

At the outset of the field surveys, VAFB personnel provided maps and a tour of four proposed turbine installation locations. Before initiating the field studies, we reviewed the results of standard database searches to obtain a list of federally listed and state-sensitive resources that are known or suspected to occur in the region. The results of these preliminary database searches provided a basis for addressing the appropriate sensitive resources in the study sites. For 
example, information was obtained on regional sensitive wildlife and habitats from the California Natural Diversity Data Base (CNDDB: Surf and Casmalia USGS 7.5 min. quad maps).

For this project, we followed established guidelines for a Level 1 approach intended for prepermitting baseline evaluations to detect relatively large effects (Anderson et al. 1999). Two types of surveys were used for this project: bird point counts and raptor activity counts. Point counts are most often used to quantify abundance of common species and are not entirely reliable to identify use by rarer species.

Six morning visits were made to each of the four study sites to observe and count general bird use. These were scheduled at approximately equal intervals between late November 2001 and May 2002. The sampling period was completed before the end of the breeding season by several bird species for contractual reasons and because recording species occurrence, rather than frequency of individuals, was a primary objective.

Each site visit occurred between $0600 \mathrm{hrs}$ and $0930 \mathrm{hrs}$. Visibility varied from foggy to lightly overcast. Temperatures ranged from $44^{\circ}$ to $60^{\circ} \mathrm{F}$, and wind conditions varied from calm $(<1$ $\mathrm{mph})$ to a light breeze $(<15 \mathrm{mph})$.

Each bird survey consisted of 60 minutes of observing and recording all bird observations within the 200-m study areas. The observer walked short distances and stopped for 1 minute, recorded all birds observed, then moved on a short distance and repeated the point count. Birds were not counted between stations. This process was repeated for the 60 -minute count and resulted in relatively even survey coverage by the observer over the entire study area.

Every effort was made to avoid disturbing birds, and the observer noted bird movements to minimize double counting of individuals as much as possible. The observer recorded species observed and the number of individuals encountered. These data were recorded in field notes and later summarized in electronic spreadsheets.

Raptor activity counts were conducted at the four study sites between late November 2001 and May 2002. The same four study sites were visited, but on days different from those when the morning bird counts were conducted. These raptor activity counts were completed between 1000 and 1600 hours. Visibility varied from foggy to slightly overcast. Temperatures ranged between $47^{\circ}$ and $60^{\circ} \mathrm{F}$, and the wind conditions varied from calm $(<1 \mathrm{mph})$ to a light wind $(\sim 20 \mathrm{mph})$.

The raptor activity counts consisted of an observer arriving at the sites and positioning himself at a fixed observation point, generally out of view of passing raptors. The observer remained at that location for 60 minutes and recorded all raptors that passed over $\left(360^{\circ}\right.$ visual scan $)$ or flew immediately adjacent to the study area. These data were recorded in field notes and later summarized in electronic spreadsheets.

We conducted no special field studies to determine the presence of bats. Instead, this assessment relied on (1) a reconnaissance-level habitat assessment of each of the four study sites and, more heavily, on (2) the results of a comprehensive survey of bats and their occurrence throughout the base (Pierson et al. 2002). 


\subsection{Results}

\subsection{General Bird Use: Results of 60-Minute, 200-m Radius Surveys}

Between 29 November 2001 and 1 May 2002, we recorded 1,588 bird sightings during six point count events at each of the four sites. Forty species were represented in the results (Tables 1a-d). Ten $(25 \%)$ of the species were common to each of the four sites. Eight $(20 \%)$ were common to three of the four sites. Another eight (20\%) were common to two of the four sites. Fourteen $(35 \%)$ species were recorded at only one of the four sites.

White-crowned sparrows were the most commonly observed species, with mean frequencies per survey of 15.0 at Site 4,11.7 at Site 2, 10.8 at Site 1, and 10.0 at Site 3. Bushtits were the second most common species observed, but they were reported only at Sites 2 and 4.

VAFB and the four study sites support a rich assemblage of bird life. Forty bird species were present during six survey events at four sites; however, the species richness per site was lower. Twenty-nine species were recorded at Site 1, with the mean number of species per survey event being 19.7. Twenty-two species were recorded at Site 3, with the mean number of species per survey event being 15.7. Twenty-five species were recorded at Site 4, with the mean number of species per survey being 18.0. Eighteen species were recorded at Site 5, with the mean number of species per survey being 15.0.

Turkey vultures, red-tailed hawks, and American kestrels were recorded at all four sites during the surveys. Northern harriers were recorded at Sites 1-3. Prairie falcons were observed at Sites 3 and 4. Red-shouldered hawks were observed at Sites 2 and 3. Additional data are provided on raptor use based on surveys conducted specifically for this group (see Methods).

Species occurrence varied throughout the sampling period. We observed a general reduction in species richness at each of the four sites over time, and we summarized both by month (Tables 1a-d). Many migrant species are in the area during the fall and winter. As these species depart for their breeding grounds, the number of birds species observed declined. The highest number of species per sampling event occurred in the 29-30 November sampling event (Site 1, $\mathrm{n}=25$ species). The lowest number of species per sampling event occurred in the 30 April-1 May sample at each of the four sites. In that period, Site 3 had the lowest species richness ( $\mathrm{n}=10$ species) for any sampling event. Species occurrence may be under-represented because some fall migrants may have been undetected as a result of the sampling schedule.

The species present were predominantly ground and shrub-nesting species. Among these are such species as black phoebes, wrentits, blue-grey gnatcatchers, hermit thrushes, California thrashers, spotted towhees, California towhees, California quail, golden-crowned and whitecrowned sparrows, and northern harriers. Except for harriers, most of these species are seen only rarely away from cover, especially dense shrubs.

Figure 3 shows the proximity of the proposed turbine sites in relation to the known occurrences of several sensitive bird species (data from Holmgren and Collins 1999). Sites 3 and 4 appear to have the greatest potential conflict in terms of sensitive species presence nearby. Burrowing owls (Athene cunicularia hypugea) are a species of particular concern with respect to siting wind turbines. Recent studies in the Altamont Pass Wind Resource Area show that burrowing owls are highly vulnerable to being killed by wind turbines (Smallwood and Thelander 2004). This California Species of Special Concern has been observed near each of the four proposed sites. 


\subsection{Raptor Activity: Results of Raptor Surveys}

Tables 2a-d summarize the findings of six raptor surveys conducted at each of the four project sites from 29-30 November 2001 through 30 April-1 May 2002. Red-tailed hawks and American kestrels were present during morning and afternoon counts conducted at each of the four study sites. Northern harriers were commonly observed in three of the four sites.

One prairie falcon was observed on 13 December 2001 at Site 5. It is relatively unusual for this species to occur so close to the coastline. Peregrine falcons are more commonly seen in coastal and near-coastal habitats on VAFB. None of the latter species was observed during the six surveys.

Two relatively common accipiters, which were noticeably absent from the survey results, occur in the area. Cooper's hawks (Accipiter cooperii) nest throughout central California and are frequently observed in the region throughout the year. Sharp-shinned hawks (Accipiter striatus) only rarely nest in central California, but they are commonly observed while on migration during the non-breeding months ( $\sim$ September-March).

Owl species are absent from the results because nighttime calling efforts were not conducted. It is likely that several species of owls, including great horned owls (Bubo virginianus), barn owls (Tyto alba), burrowing owls, and possibly western screech owls (Otus kennicotti) would frequent most or all of the study sites nocturnally.

\subsection{Bats}

To assist in assessing potential bat species occurrence and activity at the sites, we relied on a previously conducted bat survey of VAFB (Pierson et al. 2002; Figure 4). A summary of the relevant study information that relates to the current project's objectives follows.

The bat fauna of California's central coast region consists of 20 bat species. At least 10 of these occur on VAFB (Table 3); five are considered sensitive species. Pierson et al. (2002) detected bats at 194 sampling localities during bat surveys conducted on VAFB between April 1997 and July 1999. All 10 bat species were present in the spring, summer, and fall; five bat species were present in the winter. Bats were detected in all habitat types found on the base; however, most were found along stream drainages and in woodlands. Some were found in shrublands. The researchers found 98 roosts being used by seven bat species on the base. Of the four roost types recorded, artificial structures were used most frequently.

Bat activity is divided into two basic ecologies: roosting and foraging. During roosting, bats use three types of roosts: crevices, cavities, and foliage. Cavities would include caves or large tree hallows. Crevices may include rock crevices and other narrow structures, exfoliating tree bark and snags. Foliage includes trees with large branches and dense canopies. With the exception of a few bats that roost in foliage, most bats choose cave-like or artificial structures. Thirteen of the seventeen bats that occur on VAFB use artificial structures. During the summer months, bats occupy one day and one or more night roosts. Night roosts are typically located near foraging areas. This provides an opportunity to process insects, feed dependent young, and participate in social interaction. Day roosts are chosen for low disturbance, protection from predators, and warmth. Bats tend to roost in three colony sizes, large (from 100 to several thousand), smaller (several dozen to several hundred), and very small or non-colonial. 
All bat species occurring on VAFB are primarily insectivorous, except for some that also eat arthropods. Some bats feed near the ground, over water, and in riparian zones. Others feed in the canopy of trees in meadows and forested areas.

Five sensitive bat species occur on VAFB (Table 3): western mastiff bat (Eumops perotis), pallid bat (Antrozous pallidus), Townsend's big-eared bat (Corynorhinus townsendii), red bat (Lasiurus blossevilli), and Yuma myotis (Myotis yumanensis).

The Yuma myotis was the fourth most frequently observed bat on the base, forming relatively large colonies. Pallid bats (the seventh most frequently observed bat species) and Townsend's big-eared bats (the sixth most frequently observed bat) form relatively small colonies.

Pierson et al. located 20 roosts used by Townsend's big-eared bats, plus six pallid bat roosts. Approximately 12 roosts were located for the Yuma myotis. Approximately seven roosts were located for the red bat. No western mastiff bat roosts are known on VAFB, but the species occurs there occasionally. It is suspected that one or more roosts are established in Santa Ynez Valley (or nearby) and that occasionally individuals from those roosts may forage on VAFB.

Pallid bats roost predominately in natural crevices. Their main food source is large arthropods (20-70 $\mathrm{mm})$ caught on the ground, or taken from vegetation. On VAFB, they forage at night in open woodlands or forested canyons. Their typical colony size is 30-70 bats. Colonies form in the spring and stay together until fall. A significant population was found in upper Honda Canyon using stands of tan or coast live oaks for roosting.

Townsend's big-eared bats roost during the day predominately in caves; however, the species also uses mine tunnels, abandoned buildings, and cave-like attics. The typical colony size reported in California is 70-150 bats. Colonies form in the spring and stay together until the fall. They forage on moths; however, they also eat other insects. They occupy a variety of habitats and are widely distributed on VAFB at Curly Road/El Rancho Road Junction in the north part of VAFB.

Red bats generally roost in the daytime and forage at night. Typically, they hang on the underside of overhanging leaves. These bats are non-colonial. Red bats are mostly found in cottonwood/sycamore riparian stands; however, they have been found in orchards. They forage on insects that are taken while flying. These bats are mostly associated with creek drainages.

Yuma myotis bats roost in natural crevices. This species is primarily associated with water. They forage over water and feed on aquatic insects, with their diet consisting mainly of moths. This bat forms colonies in the spring that stay together until late summer. This species appears to be concentrated in the northern portion of VAFB.

Western mastiff bats roost predominately in natural crevices. Natural roosts are found usually under granite or sandstone boulders, on cliff faces, and in large boulders. Colonies range typically from 100 to 200 bats. This species occurs throughout the year on VAFB. Mastiff bats roost during the daytime and forage at night, mainly on moths. These bats are very rare on the base, although individuals have been detected acoustically in upper Honda Canyon.

Few habitat features that would appear to attract or concentrate relatively large numbers of bats, or support roosts, are present at the proposed wind turbine sites, or immediately adjacent to them. Most of the water bodies, riparian area, and woodlands are located elsewhere. The one exception may be Site 5 (Honda Ridge Road, see above) where there are numerous rocky outcrops, cliffs, 
and caves in the immediate area. This is one of the few areas on VAFB where western mastiff bats have been recorded.

\subsection{Other Sensitive Resources}

VAFB supports several threatened, endangered, and sensitive wildlife species, as well as more common bird species protected by the federal Migratory Bird Treaty Act. A search of the CNDDB revealed occurrence records for the following sensitive wildlife species in the general area of the proposed project. Some of these species may occur periodically at or near the four project sites. The sensitive bird species known or likely to occur on VAFB are listed in Table 4, along with their legal status.

The following are brief descriptions of sensitive wildlife species known to occur near the proposed facilities or for which suitable habitat was observed at one or more project sites.

Western snowy plovers (Charadrius alexandrinus nivosus) are a federally threatened species that nest in coastal dune habitats on VAFB. Snowy plovers will forage for food along the coast and in nearby wetlands. Breeding colonies exist along the coastline, but this species rarely travels inland; therefore, no suitable habitat is present at any of the proposed turbine sites.

California least terns (Sterna antillarum browni) are federal and state endangered species that occur in beach dune habitat from San Francisco to northern Baja. Least tern breeding sites occur on VAFB along the coastline. It is unlikely that terns use the proposed turbine sites, given the absence of water.

Monarch butterflies (Danaus plexippus) are a California species of special concern. They occur most commonly and in concentrations in association with stands of Eucalyptus trees. No suitable habitat for this species was found in close proximity to any of the proposed turbine sites. Therefore, no significant impacts to this species are expected.

Southwestern pond turtles (Clemmys marmorta pallida) are a California species of special concern. They are found most commonly in association with permanent freshwater sources. Because none of the sites is located in or near permanent freshwater habitats, no significant impacts to this species are expected.

California horned lizards (Phrynosoma cornatum frontale) are a federal species of concern. They occur typically in open areas of chaparral and scrub vegetation. This species may occur in any of the four proposed sites, though none was seen while observers were visiting the sites. No specific surveys for reptiles were conducted.

Two-striped garter snake (Thamnophis hammondi) is a California species of special concern. They occur in a variety of mesic habitats in coastal California from Salinas to northwestern Baja. This species may occur in any of the proposed project sites, but this would likely be a rare occurrence because of the arid conditions at each of them.

California red-legged frogs (Rana aurora aurora) occur in permanent freshwater streams with deep pools. Suitable habitat for this species does not occur at or near the four proposed turbines sites; therefore, no significant impacts to this species are expected.

The tidewater goby (Eucyclogobius newberryi) is a federally endangered species that occurs in marine estuarine and tide pool systems. None of the proposed project sites provides suitable 
habitat for this fish species; therefore, no significant impacts to this endangered species are expected.

The unarmored threespine stickleback (Gasterosteus aculeatus williamsoni) is a federally endangered species that occurs in weedy pools, backwaters, and among emergent vegetation along the edges of streams in southern California. Because no streams occur at or near any of the proposed project sites, no significant impacts to this species are expected.

The southern California steelhead (Oncorhynchus mykiss irideus) is a federally endangered species that occurs in rivers from the Santa Maria River south to San Diego. Because no streams occur at or near any of the proposed project sites, no significant impacts to this species are expected.

Horned larks (Eremophila alpestris) are a California species of special concern. This species occurs on the base and was observed during our surveys. Horned larks prefer areas with short, sparse herbaceous vegetation with little or no woody vegetation. Preferred habitats include cropland, herbaceous fencerows, road rights-of-way, pasture, recently cut hay fields, and shrubsteppe. None of the proposed sites occurs in preferred habitat for horned larks; therefore, while they occur on VAFB and may be impacted, no significant impacts to this species are expected.

VAFB provides suitable habitat for a wide range of raptors. Peregrine falcons, a state endangered species, may be impacted by the proposed project. Though we did not observe peregrines at the study sites, it is likely they occasionally forage over most of VAFB. Additionally, there are two known and recently occupied peregrine falcon nesting sites on the base, one each in the southern and the northern portions of the base. In addition, VAFB has been used as a hack site for peregrine falcon releases conducted each year by the Predatory Bird Research Group, University of California, Santa Cruz. Given the relatively high level of activity by peregrines on VAFB, peregrine interactions with wind turbines seem very likely if the proposed wind turbines are installed.

Northern harriers (Circus cyaneus) are a federal nongame bird of management concern and a California species of special concern. They occur in open, low, woody or herbaceous vegetation. They typically fly relatively low to the ground, making them vulnerable to collisions with wind turbine blades (Smallwood and Thelander 2004; Thelander et al. 2001 and 2003). This species was observed in the study area; therefore, impacts to this species may occur.

Prairie falcons (Falco mexicanus) are a California species of special concern. They are relatively rare vagrants on VAFB (Holmgren and Collins 1999) in comparison to peregrine falcons, for example, mainly because of the close proximity of the base to the coastline. One was seen at Site 5 during our surveys. Prairie falcons typically occupy open treeless terrain including prairies, deserts, riverine escarpments, canyons, foothills, and mountains; therefore, impacts to this species may occur on VAFB, but the rarity of this species will reduce the likelihood of interactions with wind turbines.

As mentioned above, burrowing owls are a California Species of Special Concern that is highly vulnerable to negative impacts from wind turbines. Special attention should be given to this species in future assessments, plus pre- and post-construction monitoring. 


\subsection{Discussion and Recommendations}

Although it is impossible, based on the data presented here, to predict which bird species, if any, will be affected by wind turbines installed on VAFB, bird species richness and relative abundance appear great enough at all four sites studied to warrant post-construction monitoring of any wind turbines constructed at VAFB. The overall species richness and the frequency of occurrence of birds on VAFB indicate a rich assemblage of birdlife. By comparison, there are more species and individuals present at each of the four VAFB sites than are present at constructed wind facilities in arid, desert areas such as the San Gregorio Pass Wind Resource Area in Palm Spring, California, or the Ponnequin Wind Energy Project in Wyoming and Colorado (R. Anderson, California Energy Commission, pers. comm.; Kerlinger et al. 2000). In both of these projects, post-construction monitoring documented that bird fatalities occurred, but in relatively low numbers per turbine per year.

The four proposed turbine sites are located far from the coastline, freshwater ponds, or riparian habitat. Several sensitive species known to frequent VAFB are dependent on these habitat types. As a result, little interaction with the proposed turbines is expected by these species. However, for wider-ranging species, especially raptors, the proposed turbine locations are in areas that may result in occasional fatalities.

In areas where raptors are abundant, such as in the Altamont Pass Wind Resource Area, relatively large numbers of individuals are killed per turbine per year (Thelander et al. 2001, 2003). Tables 2a-d summarize the findings of six point counts conducted at each of the four project sites from 29-30 November 2001 through 30 April-1 May 2002. Pre-construction late breeding season and fall bird monitoring should be conducted to further assess bird use during these time periods. Such new data combined with the results of the current surveys may yield recommendations for seasonal changes in turbine operating schedules or other measures to minimize bird fatalities.

Raptors do not appear to be present at any of the four study sites in numbers comparable to those present in the Altamont Pass Wind Resource Area (WRA). Red-tailed hawks and American kestrels were present during morning and afternoon counts conducted at each of the four VAFB study sites. Northern harriers were commonly observed in three of the four sites. Burrowing owls occur in the area but they were not observed at the project sites specifically. Each of these species has been reported killed by wind turbines in the Altamont Pass WRA and elsewhere. It therefore is likely that some raptor fatalities can be expected to occur because of the proposed project. This will depend on a number of factors, such as tower and turbine configurations, rotor diameter, rotational speeds, etc. In addition, the impact of wind turbines on any species is relative to the number of individuals present locally. The proportion of resident raptors killed may be relatively high, even if few fatalities are discovered, and thus may have a significant local effect on the distribution and abundance of that species. For these reasons, postconstruction monitoring of fatalities and bird use is recommended at wind turbines constructed on VAFB.

Peregrine falcons, a state endangered species that breeds on VAFB, occupy large nesting territories and probably forage over the entire base. This species was not observed during this study's surveys; however, VAFB records indicate the presence of two active nesting territories per year in recent years. In addition, given the base's relatively undisturbed coastline and other suitable habitat supporting numerous potential prey species, additional migrant peregrines are likely to frequent the base from late summer through early spring. The locations of the proposed 
turbines may at any time be visited by peregrines; therefore, it is reasonable to conclude that post-construction fatalities may occur given the aerial hunting strategies and the wide-ranging nature of this species.

California least tern and snowy plovers are two additional sensitive bird species that VAFB has put much effort into conserving and protecting. With the proposed inland and elevated locations of the turbines, it is unlikely that turbines will impact either of these species, both of which are closely associated with coastline habitats and water.

Based on habitat conditions, topography, and the results of field studies, Site 5 (Honda Ridge Road) probably has the greatest potential for causing bird fatalities, and it is located near one of the few known use area for western mastiff bats. Site 5 is located adjacent to a ridgeline that is near the highest point on VAFB. Several habitat types occur here, including small cliffs and escarpments and woodlands. It appears to be a natural flyway for raptors and a significant land form that must be crossed for north-south movements.

There were no obvious structures or habitat features at or near (within $0.5 \mathrm{mi}$ ) each study site that would predict the occurrence of relatively large number of bats. We made no effort to visit the sites at dusk or in darkness. Some of the raptor point counts were conducted late enough, however, to have possibly encountered bats, but none were observed.

At least 10 bat species occur on VAFB, and five are considered sensitive species. All are widely distributed over VAFB and occur there during much of the year. The extent of bat use and occurrence on the base, especially during migration, combined with the documented occurrence of at least five sensitive bat species, indicates the need for further, more detailed studies of bats in relation to the proposed turbine sites. This should include, at a minimum, post-construction monitoring of bat use and surveys for bat fatalities to determine the effects the new turbines may be having on local bat use and abundance.

Because bats are primarily nocturnal, bat fatalities may be minimized by controlling the time of day when power is generated by the proposed turbines. This and other management and mitigation techniques that will help avoid bat fatalities, if necessary, should be incorporated into the overall operation of any wind energy facility.

In summary, VAFB provides suitable habitat in a relatively undisturbed setting for a large number of sensitive and non-sensitive wildlife species. The preliminary results of this study indicate that a large number of bird (and bat) species are present in the areas proposed for wind energy development. Because the effects of the proposed project on these species and their numbers cannot be accurately predicted, post-construction wildlife monitoring should be implemented.

Once the final tower site(s) is selected, a more rigorous pre-construction survey (Phase II) and post-construction monitoring (Phase III) should be conducted. This effort should include quantification of flight heights for comparisons with turbine blade diameter and height above the ground, and it should be conducted for a 12-month annual cycle. Post-construction monitoring is warranted because pre-construction surveys cannot predict the level of fatalities that might occur. These monitoring surveys should extend for a minimum of 2 years, preferably 3 years, and they should adhere to guidelines developed by the National Wind Coordinating Committee specifically for such instances (Anderson et al. 1999). 


\subsection{Acknowledgments}

Karin Sinclair, senior project leader and technical monitor for the National Renewable Energy Laboratory, was responsible for project initiation and oversight. We thank her for her guidance and assistance throughout the project. Ken Padilla of VAFB assisted the project with logistical support, maps, access to the study sites, and other invaluable help. Nancy Read-Francine, a biologist stationed at VAFB, assisted us with wildlife occurrence information for the Base, and she referred us to Paul Collins of the Santa Barbara Natural History Museum, who also provided valuable information on the birds and bats of the Base. John Konecny (BRC) conducted the field surveys. Jim Castle (BRC) assisted with reviewing the literature on the resources of VAFB and the preparation of the report. K. Shawn Smallwood, Ph.D. reviewed and improved an earlier draft of this report. We thank three anonymous reviewers for their helpful suggestions. 


\subsection{References}

American Wind Energy Association (AWEA). 1995. Avian interactions with wind energy facilities: a summary. Prepared by Colson and Associates for AWEA, Washington D.C. 61 pp.

Anderson, R. L., M. Morrison, K. Sinclair, and D. Strickland. 1999. Studying wind energy/bird interactions: a guidance document. Metrics and methods for determining or monitoring potential impacts on birds at existing and proposed wind energy sites. Prepared for the National Wind Coordinating Committee's Avian Subcommittee. 87 pp.

Checklist of the Birds of Vandenberg Air Force Base. http://osiris.cso.uiuc.edu/denix/Public/ESPrograms/Conservation/Bird-Checklist/Vandenb/vandenb.html.

Erickson, W., G. Johnson, M. D. Strickland, D. Young, K. Sernka, and R. Good. 2001. Avian collisions with wind turbines: a summary of existing studies and comparisons to other sources of avian collision mortality in the United States. Report prepared for National Wind Coordinating Committee (Washington, D.C.) by Western Ecosystems Technology, Inc., 62 pp.

Ferren, W., C. Gillespie, and J. Gallo. 1999. Habitat classifications for wetlands and uplands of VAFB. Appendix IV. Pp. IV 1-74, in M. A. Holmgren and P. W. Collins, eds. Distribution and habitat associations of six bird species of special concern at Vandenberg Air Force Base, Santa Barbara County, California. Santa Barbara Museum of Natural History Monographs No. 1. Studies in Biodiversity No. 1.

Holmgren, M.A. and P.W. Collins (eds.). 1999. Distribution and habitat associations of six bird species of special concern at Vandenberg Air Force Base, Santa Barbara County, California. University of California, Santa Barbara, Museum of Systematics and Ecology, Environmental Report No. 7 and Santa Barbara Museum of Natural History Monograph: Studies in Biodiversity No. 1. 241 pp.

Kerlinger, P., R. Curry, and R. Ryder. 2000. Ponnequin wind energy project: reference site avian study January 1, 1998 through December 31, 1998. Report to National Renewable Energy Laboratory. Subcontract No. TAT-8-17224-01. 26 p. NREL Report No. SR-500-27546. 26 pp.

Lafferty, K.D. 2000. Status, trends and conservation of the western snowy plover with a focus on the Devereux Slough population at Coal Oil Point Reserve, Santa Barbara County, CA. Museum of Systematics and Ecology Environmental Report No. 15, University of California, Santa Barbara. $17 \mathrm{pp}$.

La Purisima Audubon Society. 2002. http://lpas.westhost.com/birdlists.htm.

Morrison, M. L. 1996. Protocols for evaluation of existing wind developments and determination of bird mortality. In: Proceedings of National Avian-Wind Power Planning Meeting II. Palm Springs, California, 20-22 Sept. 1995. Prepared for the Avian Subcommittee of the National Wind Coordination Committee by RESOLVE, Inc., Washington, D.C., and LGL Lt., King City, Ontario. $152 \mathrm{pp}$.

Morrison, M. L., and K. C. Sinclair. 1997. Overview of the U.S. Department of Energy/National Renewable Energy Laboratory Avian Research Program. Presented at the conference: Windpower'97 in Austin, Texas (June 1997). 9 pp.

National Audubon Society. 2001. Americans Birds. The $101^{\text {st }}$ Christmas Bird Count, pp. 558-579.

Pierson, E., P. Collins, W. Rainey, P. Heady, and C. Corben. 2002. Distribution, status, and habitat associations of bat species on Vandenberg Air Force Base, Santa Barbara County, California. Santa Barbara Museum of Natural History Technical Reports - No. 1. 135 pp. 
Smallwood, K. S. and C. G. Thelander. 2004. Developing methods to reduce bird mortality in the Altamont Pass Wind Resource Area. Final Report by BioResource Consultants to the California Energy Commission, Public Interest Energy Research - Environmental Area, Contract No. 50001-019:L. Spiegel, Program Manager. 363 pp. + appendices.

Thelander, C. G., S. Smallwood, and L. Rugge. 2001. Bird risk behaviors and fatalities at the Altamont Wind Resource Area - a progress report. Proceedings of the American Wind Energy Association's Annual Meeting, 7 June 2001, Washington D.C. 17 pp.

Thelander, C. G., S. Smallwood, and L. Rugge. 2003. Bird risk behaviors and fatalities at the Altamont Wind Resource Area - March 1998 to December 2000. Progress Report to the National Renewable Energy Laboratory, Subcontract No. LAT-1-30222-01. K. Sinclair, Technical Monitor. 86 pp. 
Table 1a-d. Results of Bird Species Occurrence and Frequency for Six Point Count Surveys Completed at Sites 1, 3, 4, and 5 on VAFB between 29 November 2001 and 1 May 2002

Table 1a

\begin{tabular}{|c|c|c|c|c|c|c|c|c|}
\hline $\begin{array}{c}\text { SITE } 1 \\
\text { Orion Road }\end{array}$ & $\begin{array}{c}30 \text { Nov } \\
2001\end{array}$ & $\begin{array}{c}14 \text { Dec } \\
2001\end{array}$ & $\begin{array}{l}30 \text { Jan } \\
2002\end{array}$ & $\begin{array}{c}26 \text { Feb } \\
2002\end{array}$ & $\begin{array}{c}27 \text { Mar } \\
2002\end{array}$ & $\begin{array}{c}30 \text { Apr } \\
2002\end{array}$ & Sum & Mean \pm SD \\
\hline Turkey Vulture & 3 & 4 & 0 & 4 & 3 & 0 & 14 & $2.3 \pm 1.86$ \\
\hline Northern Harrier & 0 & 0 & 0 & 0 & 1 & 0 & 1 & $0.2 \pm 0.41$ \\
\hline Red-tailed Hawk & 0 & 0 & 0 & 0 & 1 & 0 & 1 & $0.2 \pm 0.41$ \\
\hline American Kestrel & 1 & 1 & 0 & 0 & 0 & 0 & 2 & $0.3 \pm 0.52$ \\
\hline California Quail & 10 & 5 & 10 & 0 & 10 & 5 & 40 & $6.7 \pm 4.08$ \\
\hline Mourning Dove & 3 & 3 & 10 & 5 & 10 & 3 & 34 & $5.7 \pm 3.44$ \\
\hline Anna's Hummingbird & 2 & 2 & 3 & 2 & 3 & 1 & 13 & $2.2 \pm 0.75$ \\
\hline Nuttall's Woodpecker & 0 & 1 & 2 & 1 & 0 & 0 & 4 & $0.7 \pm 0.82$ \\
\hline Northern Flicker & 1 & 2 & 2 & 2 & 2 & 1 & 10 & $1.7 \pm 0.52$ \\
\hline Black Phoebe & 2 & 2 & 2 & 2 & 2 & 2 & 12 & $2.0 \pm 0.00$ \\
\hline Says Phoebe & 1 & 1 & 1 & 0 & 0 & 1 & 4 & $0.7 \pm 0.52$ \\
\hline Western Scrub Jay & 2 & 2 & 2 & 2 & 3 & 2 & 13 & $2.2 \pm 0.41$ \\
\hline Horned Lark & 3 & 0 & 1 & 0 & 0 & 0 & 4 & $0.7 \pm 1.21$ \\
\hline Bewick's Wren & 2 & 0 & 3 & 0 & 0 & 0 & 5 & $0.8 \pm 1.33$ \\
\hline Wrentit & 3 & 3 & 3 & 5 & 3 & 2 & 19 & $3.2 \pm 0.98$ \\
\hline Ruby-crowned Kinglet & 1 & 2 & 1 & 1 & 0 & 0 & 5 & $0.8 \pm 0.75$ \\
\hline Blue-grey Gnatcatcher & 1 & 1 & 2 & 0 & 0 & 0 & 4 & $0.7 \pm 0.82$ \\
\hline American Robin & 1 & 0 & 0 & 0 & 0 & 0 & 1 & $0.2 \pm 0.41$ \\
\hline California Thrasher & 2 & 0 & 3 & 1 & 1 & 0 & 7 & $1.2 \pm 1.17$ \\
\hline American Pipit & 0 & 0 & 3 & 0 & 0 & 0 & 3 & $0.5 \pm 1.22$ \\
\hline Yellow-rumped Warbler & 2 & 3 & 4 & 5 & 10 & 0 & 24 & $4.0 \pm 3.41$ \\
\hline Spotted Towhee & 3 & 2 & 2 & 2 & 2 & 3 & 14 & $2.3 \pm 0.52$ \\
\hline California Towhee & 5 & 10 & 5 & 3 & 5 & 5 & 33 & $5.5 \pm 2.35$ \\
\hline Golden-crowned Sparrow & 3 & 0 & 3 & 0 & 1 & 0 & 7 & $1.2 \pm 1.47$ \\
\hline White-crowned Sparrow & 10 & 15 & 10 & 15 & 15 & 0 & 65 & $10.8 \pm 5.85$ \\
\hline Song Sparrow & 2 & 3 & 1 & 2 & 3 & 2 & 13 & $2.2 \pm 0.75$ \\
\hline Western Meadowlark & 3 & 3 & 3 & 3 & 4 & 3 & 19 & $3.2 \pm 0.41$ \\
\hline Red-winged blackbird & 2 & 0 & 3 & 0 & 0 & 0 & 5 & $0.8 \pm 1.33$ \\
\hline Lesser Goldfinch & 3 & 3 & 5 & 5 & 5 & 4 & 25 & $4.2 \pm 0.98$ \\
\hline No. Species Observed & 25 & 20 & 24 & 17 & 19 & 13 & & $19.7 \pm 4.46$ \\
\hline
\end{tabular}


Table 1a-d. (continued) Results of Bird Species Occurrence and Frequency for Six Point Count Surveys Completed at Sites 1, 3, 4, and 5 on VAFB between 29 November 2001 and 1 May 2002

Table 1b

\begin{tabular}{|c|c|c|c|c|c|c|c|c|}
\hline $\begin{array}{c}\text { SITE } 3 \\
\text { EI Rancho Road }\end{array}$ & $\begin{array}{c}30 \mathrm{Nov} \\
\mathbf{2 0 0 1}\end{array}$ & $\begin{array}{c}14 \text { Dec } \\
2001\end{array}$ & $\begin{array}{c}30 \text { Jan } \\
2002\end{array}$ & $\begin{array}{c}26 \text { Feb } \\
2002\end{array}$ & $\begin{array}{c}27 \text { Mar } \\
2002\end{array}$ & $\begin{array}{c}30 \text { Apr } \\
2002\end{array}$ & Sum & Mean \pm SD \\
\hline Turkey Vulture & 2 & 0 & 0 & 3 & 1 & 2 & 8 & $1.3 \pm 1.21$ \\
\hline Northern Harrier & 0 & 1 & 0 & 0 & 1 & 0 & 2 & $0.3 \pm 0.52$ \\
\hline Red-shouldered Hawk & 1 & 0 & 0 & 1 & 0 & 0 & 2 & $0.3 \pm 0.52$ \\
\hline Red-tailed Hawk & 1 & 0 & 3 & 0 & 2 & 0 & 6 & $1.0 \pm 1.26$ \\
\hline American Kestrel & 0 & 1 & 0 & 0 & 0 & 0 & 1 & $0.2 \pm 0.41$ \\
\hline Mourning Dove & 6 & 5 & 10 & 4 & 10 & 2 & 37 & $6.2 \pm 3.25$ \\
\hline Anna's Hummingbird & 3 & 3 & 4 & 3 & 4 & 3 & 20 & $3.3 \pm 0.52$ \\
\hline Northern Flicker & 2 & 2 & 2 & 0 & 2 & 0 & 8 & $1.3 \pm 1.03$ \\
\hline Black Phoebe & 2 & 2 & 3 & 2 & 2 & 2 & 13 & $2.2 \pm 0.41$ \\
\hline No. Rough-winged Swallow & 4 & 0 & 5 & 0 & 10 & 0 & 19 & $3.2 \pm 4.02$ \\
\hline Bushtit & 15 & 15 & 15 & 10 & 15 & 10 & 80 & $13.3 \pm 2.58$ \\
\hline Wrentit & 4 & 4 & 5 & 3 & 3 & 4 & 23 & $3.8 \pm 0.75$ \\
\hline Blue-grey Gnatcatcher & 2 & 3 & 2 & 2 & 2 & 0 & 11 & $1.8 \pm 0.98$ \\
\hline Hermit Thrush & 0 & 0 & 2 & 1 & 2 & 0 & 5 & $0.8 \pm 0.98$ \\
\hline California Thrasher & 1 & 2 & 2 & 2 & 2 & 1 & 10 & $1.7 \pm 0.52$ \\
\hline Cedar Waxwing & 0 & 15 & 0 & 0 & 10 & 0 & 25 & $4.2 \pm 6.65$ \\
\hline Yellow-rumped Warbler & 5 & 8 & 5 & 2 & 5 & 0 & 25 & $4.2 \pm 2.79$ \\
\hline Spotted Towhee & 4 & 3 & 2 & 2 & 3 & 3 & 17 & $2.8 \pm 0.75$ \\
\hline California Towhee & 7 & 8 & 5 & 5 & 5 & 5 & 35 & $5.8 \pm 1.33$ \\
\hline Golden-crowned Sparrow & 6 & 5 & 0 & 1 & 0 & 0 & 12 & $2.0 \pm 2.76$ \\
\hline White-crowned Sparrow & 15 & 15 & 15 & 10 & 10 & 5 & 70 & $11.7 \pm 4.08$ \\
\hline Fox Sparrow & 1 & 1 & 0 & 0 & 0 & 0 & 2 & $0.3 \pm 0.52$ \\
\hline No. Species Observed & 19 & 17 & 15 & 15 & 18 & 10 & & $15.7 \pm 3.20$ \\
\hline
\end{tabular}


Table 1a-d. (continued) Results of Bird Species Occurrence and Frequency for Six Point Count Surveys Completed at Sites 1, 3, 4, and 5 on VAFB between 29 November 2001 and 1 May 2002

Table 1c

\begin{tabular}{|c|c|c|c|c|c|c|c|c|}
\hline $\begin{array}{c}\text { SITE } 4 \\
\text { Arguello Road }\end{array}$ & $\begin{array}{c}29 \text { Nov } \\
2001\end{array}$ & $\begin{array}{c}14 \text { Dec } \\
2001\end{array}$ & $\begin{array}{c}29 \text { Jan } \\
2002\end{array}$ & $\begin{array}{c}27 \text { Feb } \\
2002\end{array}$ & $\begin{array}{c}26 \text { Mar } \\
2002\end{array}$ & $\begin{array}{c}1 \text { May } \\
2002\end{array}$ & Sum & Mean \pm SD \\
\hline Turkey Vulture & 0 & 5 & 1 & 1 & 4 & 3 & 14 & $2.3 \pm 1.97$ \\
\hline Red-tailed Hawk & 0 & 2 & 2 & 1 & 2 & 1 & 8 & $1.3 \pm 0.82$ \\
\hline California Quail & 3 & 2 & 3 & 1 & 4 & 3 & 16 & $2.7 \pm 1.03$ \\
\hline Anna's Hummingbird & 2 & 2 & 3 & 2 & 2 & 3 & 14 & $2.3 \pm 0.52$ \\
\hline Nuttall's Woodpecker & 1 & 1 & 1 & 1 & 1 & 2 & 7 & $1.2 \pm 0.41$ \\
\hline Northern Flicker & 2 & 1 & 1 & 1 & 1 & 2 & 8 & $1.3 \pm 0.52$ \\
\hline Black Phoebe & 2 & 1 & 2 & 2 & 2 & 2 & 11 & $1.8 \pm 0.41$ \\
\hline Western Scrub Jay & 3 & 1 & 2 & 2 & 3 & 3 & 14 & $2.3 \pm 0.82$ \\
\hline Wrentit & 2 & 3 & 3 & 3 & 3 & 3 & 17 & $2.8 \pm 0.41$ \\
\hline Ruby-crowned Kinglet & 3 & 3 & 3 & 2 & 0 & 0 & 11 & $1.8 \pm 1.47$ \\
\hline Blue-grey Gnatcatcher & 1 & 2 & 0 & 0 & 1 & 0 & 4 & $0.7 \pm 0.82$ \\
\hline Hermit Thrush & 1 & 1 & 1 & 0 & 0 & 0 & 3 & $0.5 \pm 0.55$ \\
\hline California Thrasher & 3 & 1 & 2 & 1 & 1 & 1 & 9 & $1.5 \pm 0.84$ \\
\hline Orange-crowned Warbler & 0 & 0 & 0 & 0 & 3 & 2 & 5 & $0.8 \pm 1.33$ \\
\hline Yellow-rumped Warbler & 3 & 2 & 5 & 3 & 3 & 5 & 21 & $3.5 \pm 1.22$ \\
\hline Spotted Towhee & 1 & 2 & 2 & 1 & 3 & 2 & 11 & $1.8 \pm 0.75$ \\
\hline California Towhee & 5 & 5 & 5 & 3 & 5 & 3 & 26 & $4.3 \pm 1.03$ \\
\hline Golden-crowned Sparrow & 3 & 4 & 2 & 0 & 0 & 0 & 9 & $1.5 \pm 1.76$ \\
\hline White-crowned Sparrow & 15 & 15 & 5 & 15 & 10 & 0 & 60 & $10.0 \pm 6.32$ \\
\hline Song Sparrow & 3 & 3 & 2 & 2 & 4 & 3 & 17 & $2.8 \pm 0.75$ \\
\hline House Finch & 5 & 10 & 10 & 10 & 10 & 5 & 50 & $8.3 \pm 2.58$ \\
\hline No. Species Observed & 18 & 20 & 19 & 17 & 18 & 16 & & $18.0 \pm 1.41$ \\
\hline
\end{tabular}


Table 1a-d. (continued) Results of Bird Species Occurrence and Frequency for Six Point Count Surveys Completed at Sites 1, 3, 4, and 5 on VAFB between 29 November 2001 and 1 May 2002

Table 1d

\begin{tabular}{|c|c|c|c|c|c|c|c|c|}
\hline $\begin{array}{c}\text { SITE } 5 \\
\text { Honda Ridge Road }\end{array}$ & $\begin{array}{c}29 \text { Nov } \\
2001\end{array}$ & $\begin{array}{l}14 \text { Dec } \\
2001\end{array}$ & $\begin{array}{l}29 \text { Jan } \\
2002\end{array}$ & $\begin{array}{l}27 \text { Feb } \\
2002\end{array}$ & $\begin{array}{c}26 \text { Mar } \\
2002\end{array}$ & $\begin{array}{l}1 \text { May } \\
2002\end{array}$ & Sum & Mean \pm SD \\
\hline Turkey Vulture & 0 & 2 & 1 & 3 & 2 & 0 & 8 & $1.3 \pm 1.21$ \\
\hline Red-tailed Hawk & 2 & 1 & 3 & 1 & 1 & 0 & 8 & $1.3 \pm 1.03$ \\
\hline American Kestrel & 1 & 2 & 0 & 2 & 2 & 0 & 7 & $1.2 \pm 0.98$ \\
\hline Prairie Falcon & 0 & 1 & 0 & 0 & 0 & 0 & 1 & $0.2 \pm 0.41$ \\
\hline Northern Flicker & 1 & 1 & 1 & 1 & 1 & 1 & 6 & $1.0 \pm 0.00$ \\
\hline Western Scrub Jay & 3 & 1 & 2 & 2 & 1 & 2 & 11 & $1.8 \pm 0.75$ \\
\hline Common Raven & 2 & 0 & 2 & 2 & 0 & 2 & 8 & $1.3 \pm 0.75$ \\
\hline Bushtit & 10 & 15 & 15 & 15 & 15 & 10 & 80 & $13.3 \pm 2.58$ \\
\hline Bewicks's Wren & 2 & 4 & 3 & 2 & 0 & 2 & 13 & $2.2 \pm 2.58$ \\
\hline Wrentit & 3 & 3 & 3 & 3 & 3 & 3 & 18 & $3.0 \pm 0.00$ \\
\hline Ruby-crowned Kinglet & 2 & 2 & 3 & 2 & 2 & 0 & 11 & $1.8 \pm 0.98$ \\
\hline California Thrasher & 2 & 1 & 1 & 1 & 2 & 1 & 8 & $1.3 \pm 0.52$ \\
\hline European Starling & 10 & 15 & 20 & 0 & 0 & 15 & 60 & $10.0 \pm 8.37$ \\
\hline Spotted Towhee & 2 & 1 & 1 & 2 & 2 & 4 & 12 & $2.0 \pm 1.10$ \\
\hline California Towhee & 5 & 5 & 3 & 3 & 7 & 10 & 33 & $5.5 \pm 2.66$ \\
\hline Golden-crowned Sparrow & 5 & 7 & 6 & 6 & 4 & 0 & 28 & $4.7 \pm 2.50$ \\
\hline White-crowned Sparrow & 15 & 20 & 20 & 15 & 20 & 0 & 90 & $15.0 \pm 7.75$ \\
\hline Song Sparrow & 3 & 3 & 3 & 2 & 3 & 5 & 19 & $3.2 \pm 0.98$ \\
\hline No. Species Observed & 16 & 17 & 16 & 16 & 14 & 11 & & $15.0 \pm 2.19$ \\
\hline
\end{tabular}


Tables 2a-d. Results of Raptor Occurrence and Frequency for Six Surveys at Site 1 (Table 2a), Site 3 (Table 2b), Site 4 (Table 2c), and Site 5 (Table 2d) on VAFB

Table 2a

\begin{tabular}{|c|c|c|c|c|c|c|c|c|}
\hline $\begin{array}{c}\text { SITE } 1 \\
\text { Orion Road }\end{array}$ & $\begin{array}{c}30 \text { Nov } \\
2001\end{array}$ & $\begin{array}{c}13 \text { Dec } \\
2001\end{array}$ & $\begin{array}{l}29 \text { Jan } \\
2002\end{array}$ & $\begin{array}{c}26 \text { Feb } \\
2002\end{array}$ & $\begin{array}{c}26 \text { Mar } \\
2002\end{array}$ & $\begin{array}{c}30 \text { Apr } \\
2002\end{array}$ & Sum & Mean \pm SD \\
\hline Turkey Vulture & 1 & 4 & 0 & 4 & 7 & 0 & 16 & $2.7 \pm 2.80$ \\
\hline Northern Harrier & 0 & 0 & 0 & 0 & 1 & 0 & 1 & $0.2 \pm 0.41$ \\
\hline Red-tailed Hawk & 0 & 1 & 0 & 0 & 1 & 0 & 2 & $0.3 \pm 0.52$ \\
\hline American Kestrel & 3 & 1 & 0 & 0 & 0 & 0 & 4 & $0.7 \pm 1.21$ \\
\hline No. Species Observed & 2 & 3 & 0 & 1 & 3 & 0 & & $1.5 \pm 1.38$ \\
\hline
\end{tabular}

Table 2b

\begin{tabular}{|c|c|c|c|c|c|c|c|c|}
\hline $\begin{array}{c}\text { SITE } 3 \\
\text { EI Rancho Road }\end{array}$ & $\begin{array}{c}30 \text { Nov } \\
2001\end{array}$ & $\begin{array}{c}14 \text { Dec } \\
2001\end{array}$ & $\begin{array}{l}29 \text { Jan } \\
2002\end{array}$ & $\begin{array}{c}26 \text { Feb } \\
2002\end{array}$ & $\begin{array}{c}26 \text { Mar } \\
2002\end{array}$ & $\begin{array}{c}30 \text { Apr } \\
2002\end{array}$ & Sum & Mean \pm SD \\
\hline Turkey Vulture & 2 & 0 & 0 & 3 & 1 & 2 & 8 & $1.3 \pm 1.21$ \\
\hline Northern Harrier & 0 & 1 & 0 & 0 & 1 & 0 & 2 & $0.3 \pm 0.52$ \\
\hline Red-shouldered Hawk & 1 & 0 & 0 & 1 & 0 & 0 & 2 & $0.3 \pm 0.52$ \\
\hline Red-tailed Hawk & 2 & 0 & 3 & 0 & 2 & 0 & 7 & $1.2 \pm 1.33$ \\
\hline American Kestrel & 0 & 1 & 0 & 0 & 0 & 0 & 1 & $0.2 \pm 0.41$ \\
\hline No. Species Observed & 3 & 2 & 1 & 2 & 3 & 1 & & $2.0 \pm 0.89$ \\
\hline
\end{tabular}


Tables 2a-d. (continued) Results of Raptor Occurrence and Frequency for Six Surveys at Site 1 (Table 2a), Site 3 (Table 2b), Site 4 (Table 2c), and Site 5 (Table 2d) on VAFB

Table 2c

\begin{tabular}{|c|c|c|c|c|c|c|c|c|}
\hline $\begin{array}{c}\text { SITE 4 } \\
\text { Arguello Road }\end{array}$ & $\mathbf{2 9}$ Nov & $\mathbf{1 3}$ Dec & $\mathbf{2 9}$ Jan & $\mathbf{2 6}$ Feb & 27 Mar & 30 Apr & Sum & Mean \pm SD \\
\hline Turkey Vulture & 0 & 5 & 1 & 1 & 4 & 3 & 14 & $2.3 \pm 1.97$ \\
\hline Northern Harrier & 0 & 1 & 0 & 0 & 0 & 0 & 1 & $0.2 \pm 0.41$ \\
\hline Red-tailed Hawk & 0 & 2 & 2 & 1 & 2 & 1 & 8 & $1.3 \pm 0.82$ \\
\hline No. Species Observed & 0 & 3 & 2 & 2 & 2 & 2 & & $1.8 \pm 0.98$ \\
\hline
\end{tabular}

Table 2d

\begin{tabular}{|c|c|c|c|c|c|c|c|c|}
\hline $\begin{array}{c}\text { SITE } 5 \\
\text { Honda Ridge Road }\end{array}$ & $\begin{array}{l}29 \text { Nov } \\
2001\end{array}$ & $\begin{array}{l}13 \text { Dec } \\
2001\end{array}$ & $\begin{array}{l}29 \text { Jan } \\
2002\end{array}$ & $\begin{array}{c}26 \text { Feb } \\
2002\end{array}$ & $\begin{array}{c}27 \text { Mar } \\
2002\end{array}$ & $\begin{array}{c}30 \text { Apr } \\
2002\end{array}$ & Sum & Mean \pm SD \\
\hline Turkey Vulture & 0 & 2 & 1 & 3 & 2 & 0 & 8 & $1.3 \pm 1.21$ \\
\hline Red-tailed Hawk & 2 & 1 & 3 & 3 & 1 & 0 & 10 & $1.7 \pm 1.21$ \\
\hline American Kestrel & 2 & 2 & 0 & 2 & 0 & 0 & 6 & $1.0 \pm 1.10$ \\
\hline Prairie Falcon & 0 & 1 & 0 & 0 & 0 & 0 & 1 & $0.2 \pm 0.41$ \\
\hline No. Species Observed & 2 & 4 & 2 & 3 & 2 & 0 & & $2.1 \pm 1.33$ \\
\hline
\end{tabular}


Table 3. Bat Species Observed on VAFB (Source: Pierson et al. 2002)

\begin{tabular}{|l|c|}
\hline \multicolumn{1}{|c|}{ Species } & Status \\
\hline Western Mastiff Bat (Eumops perotis) & MSSC, SC \\
\hline Pallid Bat (Antrozous pallidus) & FSS, MSSC \\
\hline Townsend's Big-eared Bat (Corynorhinus townsendii) & FSS, MSSC, SC \\
\hline Red Bat (Lasiurus blossevilli) & FSS, MSSC* \\
\hline Yuma Myotis (Myotis yumanensis) & SC \\
\hline Mexican Free-tailed Bat (Tadarida brasiliensis) & None \\
\hline Big Brown Bat (Eptesicus fuscus) & None \\
\hline Silver haired Bat (Lasionycteris noctivagans) & None \\
\hline Hoary Bat (Lasiurus cinereus) & None \\
\hline California Myotis (Myotis californicus) & None \\
\hline
\end{tabular}

\footnotetext{
MSSC $=$ California Dapartment of Fish and Game Mammal Species of Special

Concern $(*=$ proposed $)$

$\mathrm{SC}=\mathrm{U} . \mathrm{S}$. Fish and Wildlife Service Special Concern

FSS $=$ USDA Forest Service Sensitive
} 
Table 4. List of Sensitive Bird Species that occur on VAFB (Source: Checklist of the Birds of Vandenberg Air Force Base)

\begin{tabular}{|c|c|c|}
\hline Common Name & Scientific Name & Status \\
\hline California Brown Pelican (roost sites) & Pelecanus occidentalis californicus & FE CE \\
\hline American Bittern & Botaurus lentiginosus & MC RR \\
\hline Western Least Bittern & Ixobrychus exilis hesperis & MC RR CSC \\
\hline Great Blue Heron & Ardea herodias & CP RR \\
\hline White-faced Ibis & Plegadis chihi & MC RR CSC \\
\hline Northern Harrier & Circus cyaneus & MC RR CSC \\
\hline White-tailed Kite & Elanus leucurus & MC RR \\
\hline Sharp-shinned Hawk & Accipiter striatus & $\mathrm{CSC}$ \\
\hline Cooper's Hawk & Accipiter cooperii & CSC RR \\
\hline Swainson's Hawk & Buteo swainsoni & CT RR \\
\hline Ferruginous Hawk & Buteo regalis & MC CSC \\
\hline Rough-legged Hawk & Buteo lagopus & RR \\
\hline Golden Eagle & Aquila chrysaetos & $\mathrm{CSC}$ \\
\hline Bald Eagle & Haliaeetus leucocephalus & FT CE RR \\
\hline Osprey & Pandion haliaetus & $\mathrm{CSC}$ \\
\hline Merlin & Falco columbarius & $\mathrm{CSC}$ \\
\hline Prairie Falcon & Falco mexicanus & CSC RR \\
\hline Peregrine Falcon & Falco peregrinus & $\mathrm{CE}$ \\
\hline California Black Rail & Laterallus jamaicensis coturniculus & MC CT RR \\
\hline Western Snowy Plover & Charadrius alexandrinus nivosus & FT CSC \\
\hline Mountain Plover & Charadrius montanus & C,MC CSC RR \\
\hline Long-billed Curlew & Numenius americanus & $\mathrm{MC} \mathrm{CSC}$ \\
\hline Elegant Tern & Sterna elegans & MC CSC \\
\hline California Least Tern & Sterna antillarum browni & FE CE \\
\hline Black Skimmer & Rynchops niger & $\mathrm{CSC}$ \\
\hline Marbled Murrelet & Brachyramphus marmoratus & FT CE RR \\
\hline Rhinoceros Auklet & Cerorhinca monocerata & CSC RR \\
\hline Western Yellow-billed Cuckoo & Coccyzus americanus occidentalis & MC CE RR \\
\hline Long-eared Owl & Asio otus & CSC RR \\
\hline Short-eared Owl & Asio flammeus & MC CSC RR \\
\hline Burrowing Owl & Athene cunicularia hypugea & MC CSC RR \\
\hline Black Swift & Cypseloides niger & MC CSC \\
\hline
\end{tabular}


Table 4. (continued) List of Sensitive Bird Species that occur on VAFB (Source: Checklist of the Birds of Vandenberg Air Force Base)

\begin{tabular}{|l|l|l|}
\hline Southwestern Willow Flycatcher & Empidonax trailii extimus & FE CE RR \\
\hline Loggerhead Shrike & Lanius ludovicianus & MC CSC RR \\
\hline Least Bell's Vireo & Vireo bellii pusillus & FE CE RR \\
\hline Horned Lark & Eremophila alpestris & CSC RR \\
\hline Purple Martin & Progne subis & CSC RR \\
\hline Bank Swallow & Riparia riparia & CT RR \\
\hline Tree Swallow & Tachycineta bicolor & RR \\
\hline Mountain Bluebird & Sialia currucoides & RR \\
\hline Yellow-breasted Chat & Icteria virens & CSC RR \\
\hline Blue Grosbeak & Guiraca caerulea & RR \\
\hline Rufous-crowned Sparrow & Aimophila ruficaps & RR \\
\hline Bell's Sage Sparrow & Amphispiza belli belli & MC CSC RR \\
\hline Grasshopper Sparrow & Ammodramus savannarium & MC RR \\
\hline Savannah Sparrow (breeding only) & Passerculus sandwichensis & RR \\
\hline Long-billed Savannah Sparrow & Passerculus sandwichensis rostratus & CSC RR \\
\hline Tricolored Blackbird & Agelaius tricolor & MC CSC RR \\
\hline
\end{tabular}

\begin{tabular}{|l|l|l|}
\hline \multicolumn{1}{|c|}{ Federal Status } & \multicolumn{1}{c|}{ State (CDFG) Status } & \multicolumn{1}{c|}{ Regional Status } \\
FE = Federally Endangered & $\mathrm{CE}=$ State Endangered \\
FT = Federally Threatened & $\mathrm{CT}=$ State Threatened \\
$\mathrm{C}=$ Federal Candidate & $\mathrm{CSC}=$ Species of Special Concern \\
$\begin{array}{l}\text { MC }=\text { Federal (USFWS) nongame bird of } \\
\text { management concern }\end{array}$ & $\mathrm{CP}=$ California Protected & \\
\hline
\end{tabular}




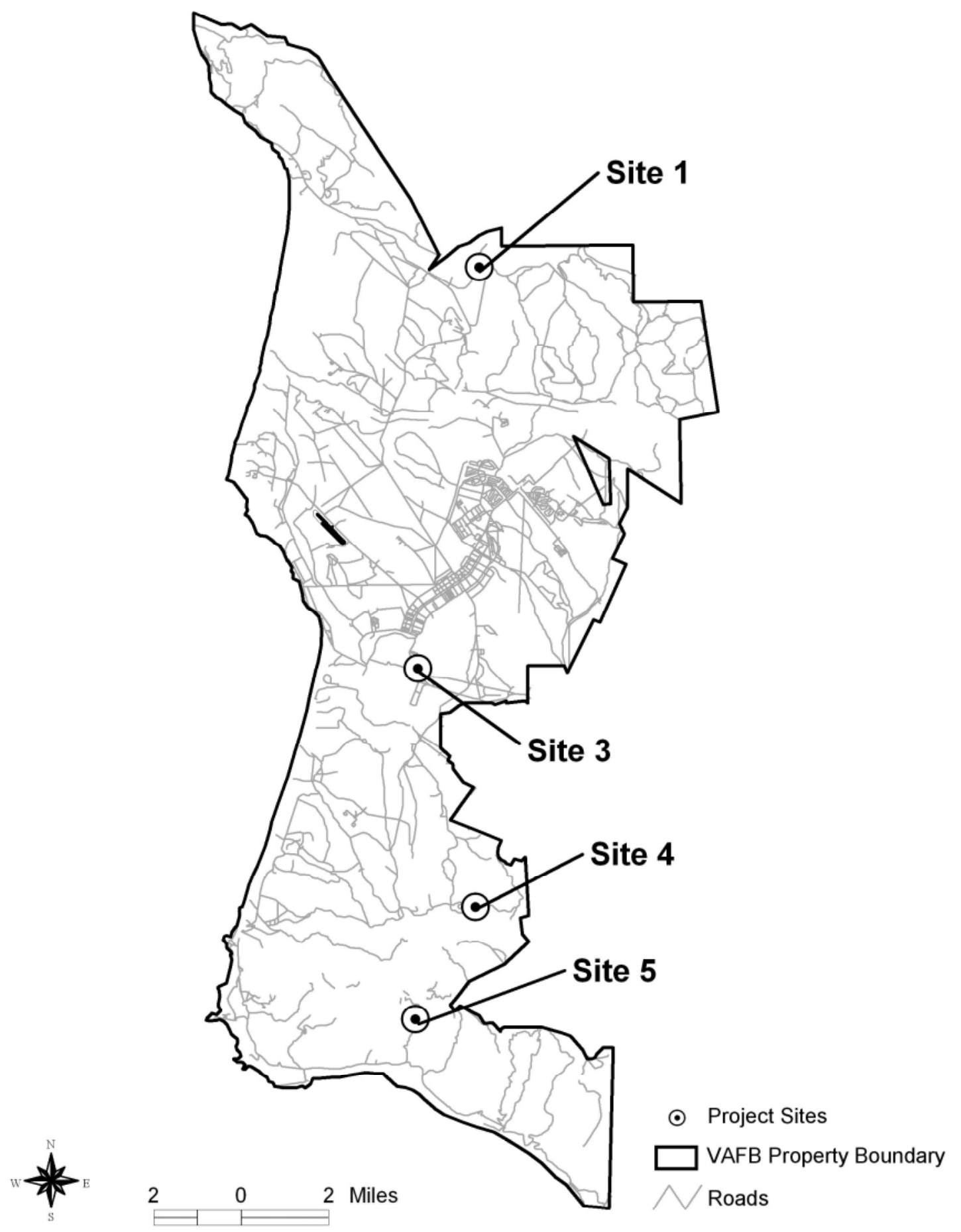

Figure 1. A general VAFB map showing the locations of Sites 1, 3, 4, and 5 


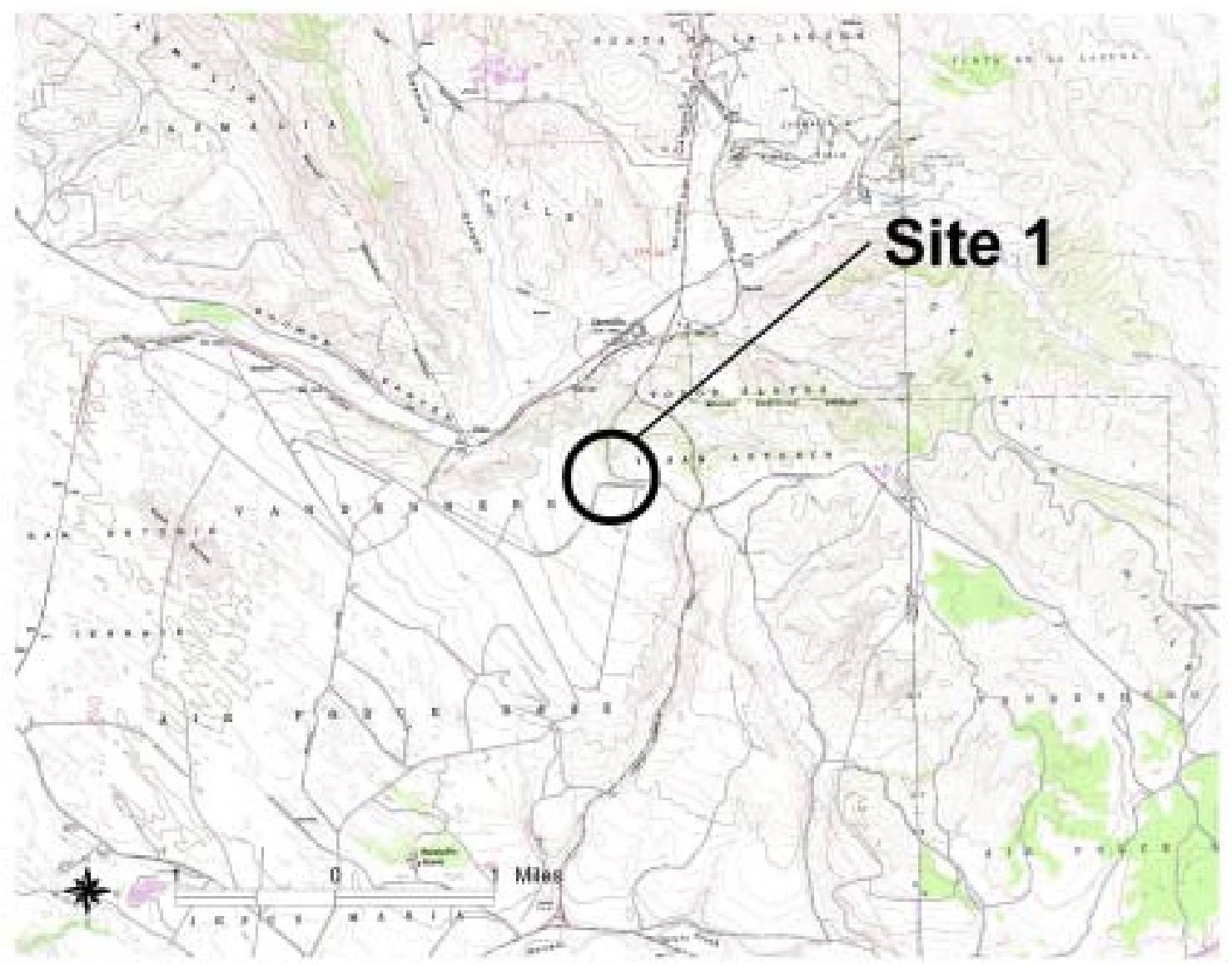

Figure 2a. Site 1, the Orion Road study site 


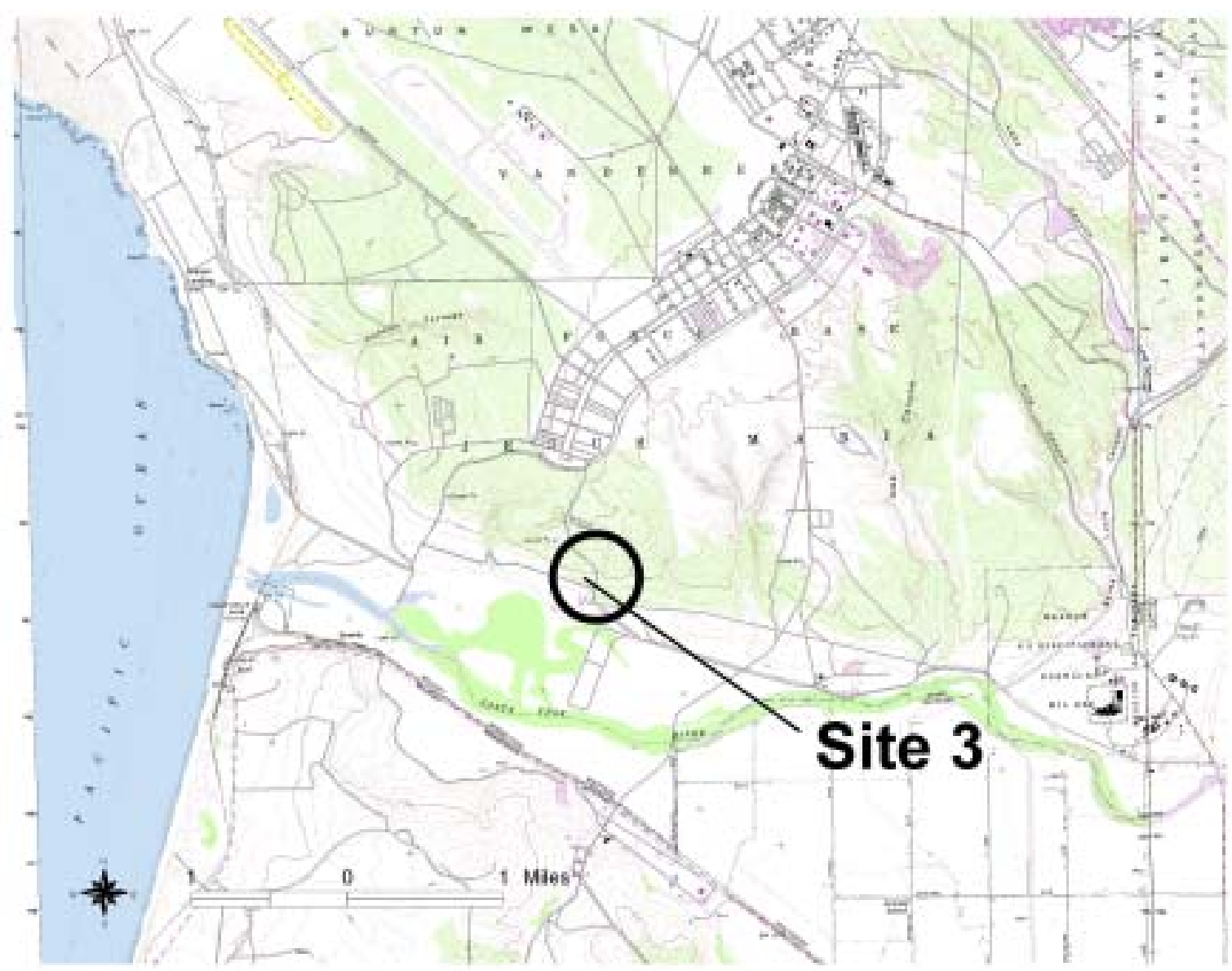

Figure 2b. Site 3, the El Rancho Road study site 


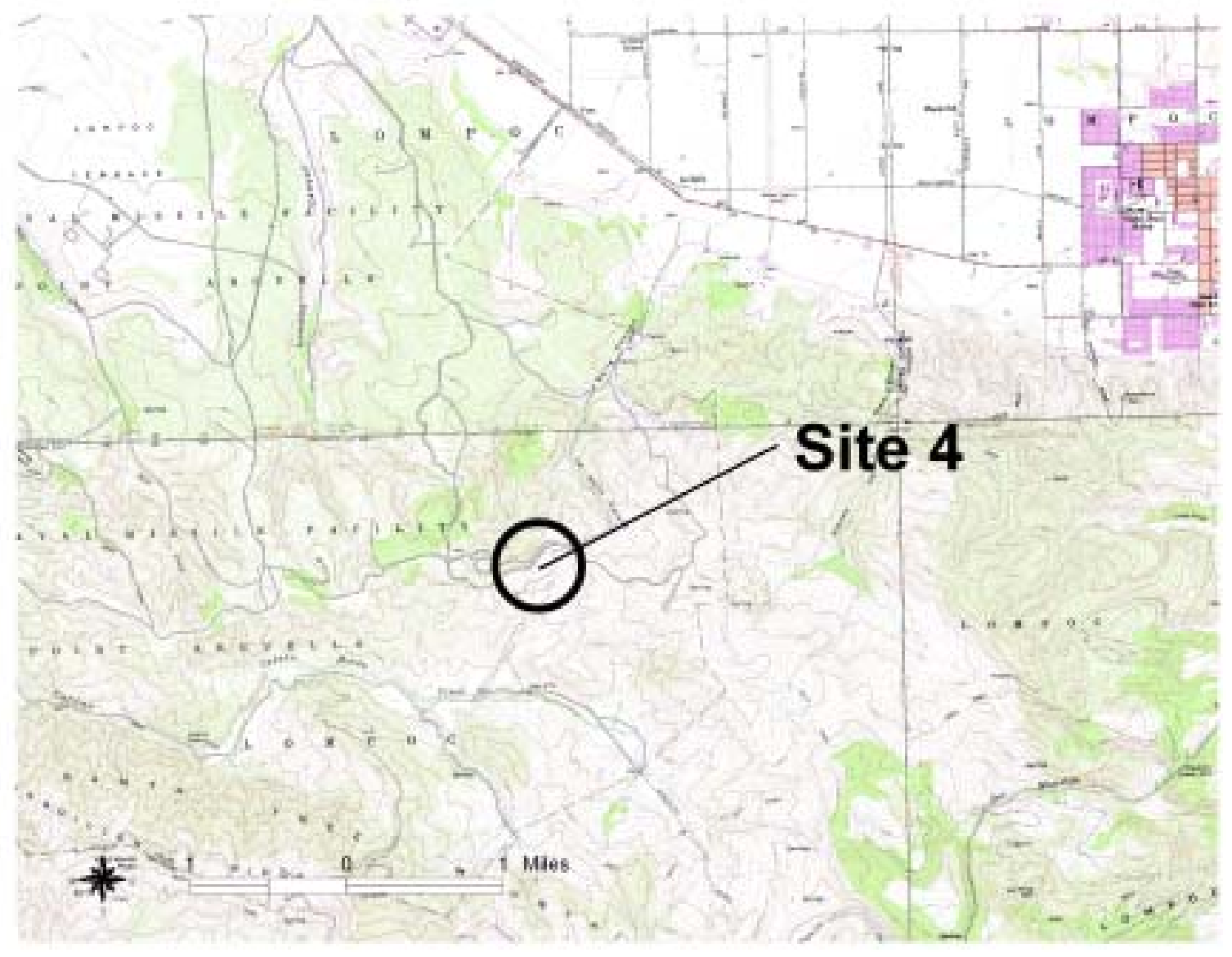

Figure 2c. Site 4: Arguello Road study site 


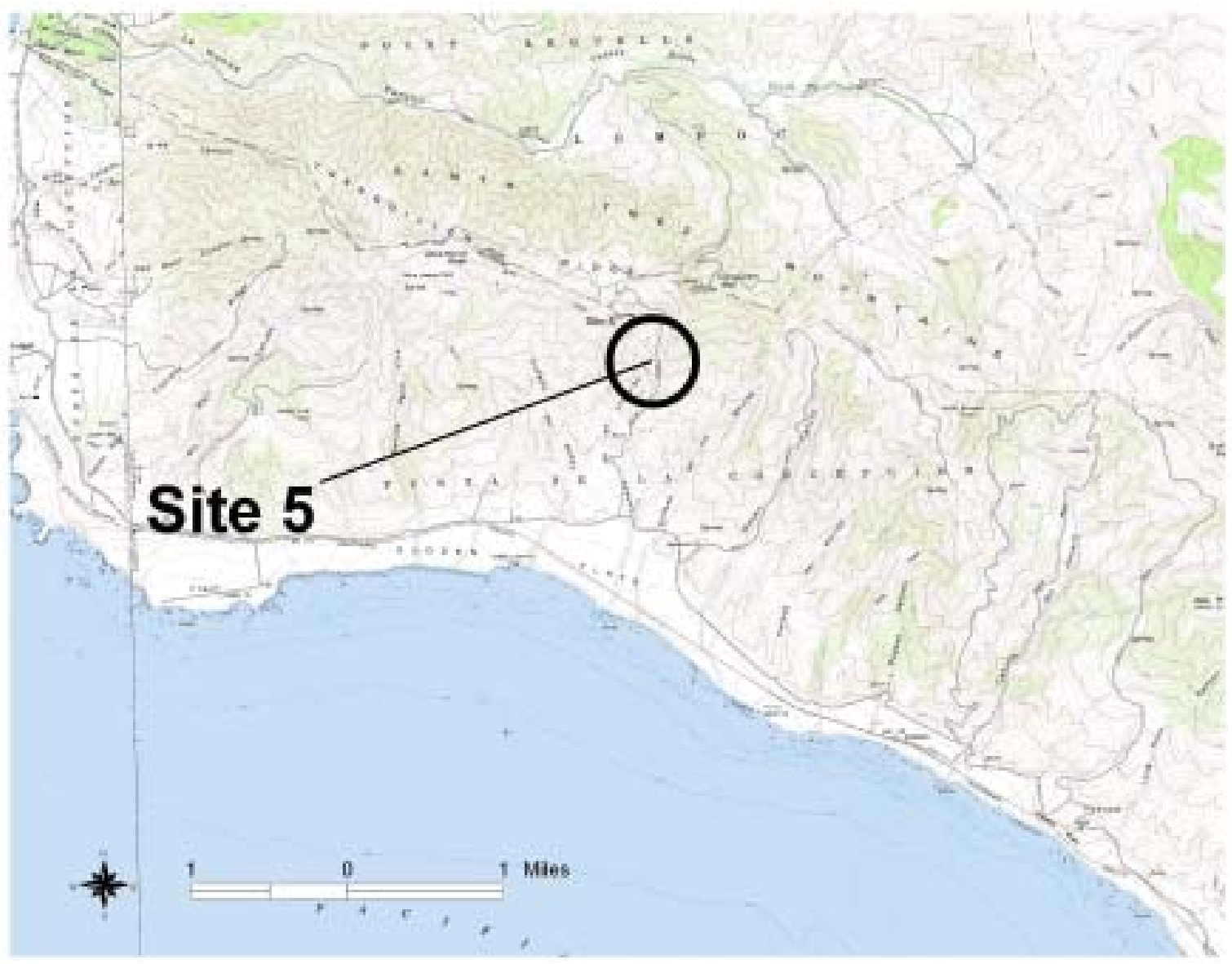

Figure 2d. Site 5: Honda Ridge Road study site 
Birds Types

4. Tricolored Blackbird Sightings

- Burrowing Owls

- Least Bittern Sightings

- Rufous-crowned Sparrow Territories

- Sage Sparrow Territories

$\odot \quad$ Project Sites

VAFB Property Boundary

Roads

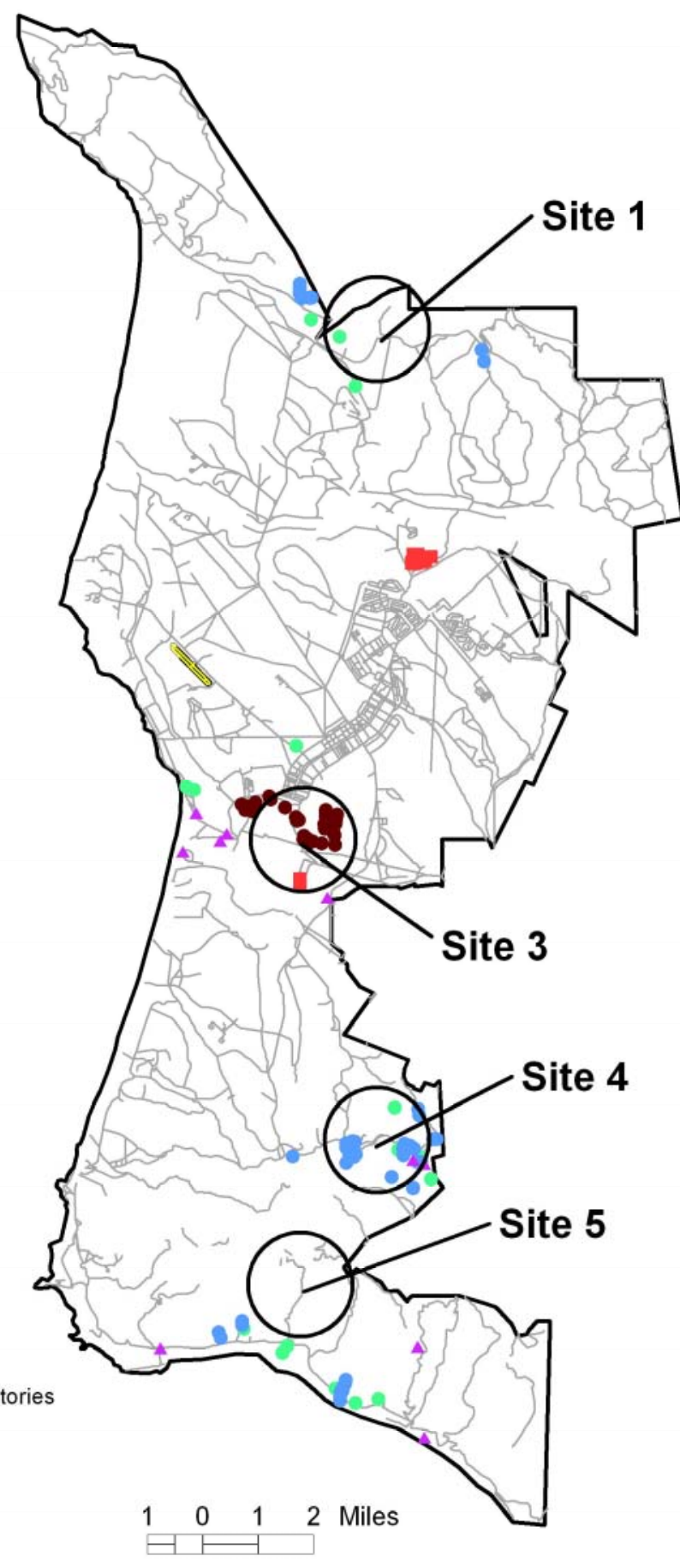

Figure 3. Distribution of occurrence records for five sensitive bird species on VAFB in relation to the four proposed project sites (data from Holmgren and Collins 1999) 


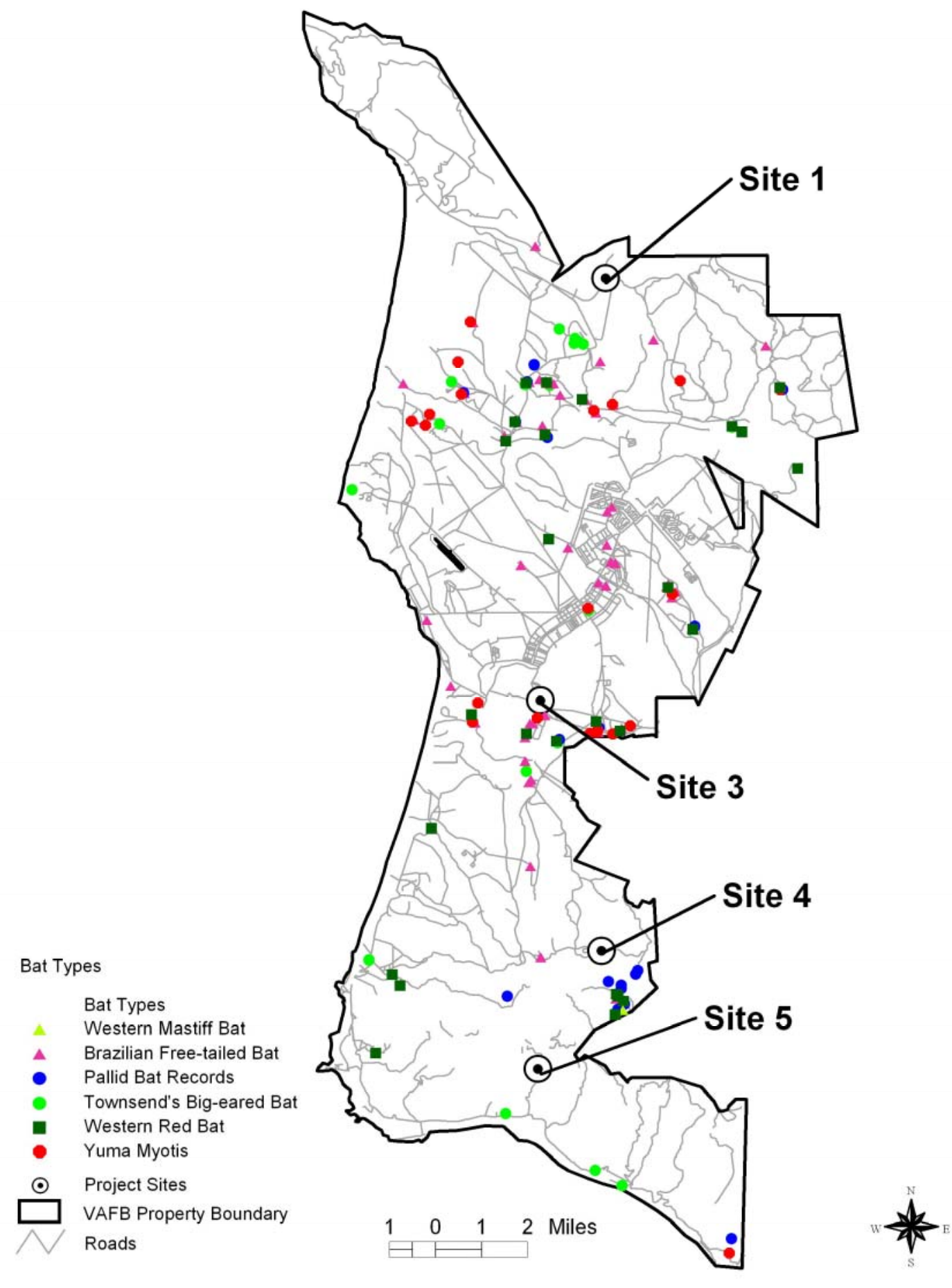

Figure 4. Distribution of occurrence for six bat species on VAFB in relation to the four proposed project sites (data from Pierson et al. 2002) 


\section{APPENDIX A: BIRD OCCURRENCE AT THE WATERFOWL NATURAL RESOURCE AREA, VANDENBERG AFB}

As of 14 July 2002: 253 species recorded

GAVIIFORMES: Red-throated Loon, Pacific Loon

PODICIPEDIIFORMES: Pied-billed Grebe, Horned Grebe, Eared Grebe, Western Grebe, Clark's Grebe

PELICANIFORMES: Double-crested Cormorant

CICONIIFORMES: American Bittern, Least Bittern, Great Blue Heron, Great Egret, Snowy Egret, Cattle Egret, Green Heron, Black-crowned Night-Heron, White-faced Ibis

\section{ANSERIFORMES:}

Geese: Greater White-fronted Goose, Snow Goose, Ross' Goose, Brant, Canada Goose

Ducks: Wood Duck, Green-winged Teal, Mallard, Northern Pintail, Garganey, Bluewinged Teal, Cinnamon Teal, Northern Shoveler, Gadwall, American Widgeon, Canvasback, Redhead, Ring-necked Duck, Greater Scaup, Lesser Scaup, Surf Scoter, Bufflehead, Hooded Merganser, Red-breasted Merganser, Ruddy Duck

FALCONIFORMES: Turkey Vulture, Osprey, White-tailed Kite, Northern Harrier, Sharpshinned Hawk, Cooper's Hawk, Red-shouldered Hawk, Broad-winged Hawk, Swainson's Hawk, Red-tailed Hawk, Ferruginous Hawk, Golden Eagle Crested Caracara (unbanded; origin uncertain), American Kestrel, Merlin, Peregrine Falcon, Prairie Falcon

GALLIFORMES: Ring-necked Pheasant (released or escaped), California Quail

GRUIFORMES: Virginia Rail, Sora, Common Moorhen, American Coot

\section{CHARADRIIFORMES:}

Plovers, stilts, avocets: Black-bellied Plover, American Golden Plover, Pacific Golden Plover, Snowy Plover, Semipalmated Plover, Killdeer, Mountain Plover, Black-necked Stilt, American Avocet

Sandpipers, phalaropes: Greater Yellowlegs, Lesser Yellowlegs, Solitary Sandpiper, Willet, Spotted Sandpiper, Whimbrel, Long-billed Curlew, Sanderling, Western Sandpiper, Least Sandpiper, Baird's Sandpiper, Pectoral Sandpiper, Dunlin, Short-billed Dowitcher, Long-billed Dowitcher, Common Snipe, Wilson's Phalarope, Red-necked Phalarope, Red Phalarope

Gulls, terns: Bonaparte's Gull, Mew Gull, Ring-billed Gull, California Gull, Western Gull, Glaucous-winged Gull, Forster's Tern, Caspian Tern

COLUMBIFORMES: Band-tailed Pigeon, Mourning Dove, White-winged Dove CUCULIFORMES: Greater Roadrunner

STRIGIFORMES: Barn Owl, Great Horned Owl, Burrowing Owl, Long-eared Owl (deceased) 


\section{APODIFORMES:}

Swifts: Black Swift, Vaux's Swift, White-throated Swift

Hummingbirds: Anna's Hummingbird, Costa's Hummingbird, Rufous Hummingbird, Allen's Hummingbird

CORACIIFORMES: Belted Kingfisher, Acorn Woodpecker, Red-naped Sapsucker, Redbreasted Sapsucker, Nuttall's Woodpecker, Downy Woodpecker, Hairy Woodpecker, Northern Flicker

\section{PASSERIFORMES:}

Flycatchers: Olive-sided Flycatcher, Western Wood-Pewee, Willow Flycatcher, Pacificslope Flycatcher, Black Phoebe, Say's Phoebe, Ash-throated Flycatcher, Tropical Kingbird, Cassin's Kingbird, Western Kingbird

Larks: Horned Lark

Swallows: Purple Martin, Tree Swallow, Violet-green Swallow, Northern Rough-winged Swallow, Bank Swallow, Cliff Swallow, Barn Swallow

Jays, crows, ravens: Western Scrub Jay, American Crow, Common Raven

Chickadees, titmouse, bushtit: Chestnut-backed Chickadee, Oak Titmouse, Bushtit

Nuthatches, wrens: Red-breasted Nuthatch, Bewick's Wren, House Wren, Winter Wren, Marsh Wren

Kinglets, gnatcatchers, thrushes: Golden-crowned Kinglet, Ruby-crowned Kinglet, Bluegray Gnatcatcher, Western Bluebird, Mountain Bluebird, Swainson's Thrush, Hermit Thrush, American Robin, Varied Thrush, Wrentit, Northern Mockingbird, Brown Thrasher, California Thrasher

Pipits, waxwing: Red-throated Pipit, American Pipit, Cedar Waxwing

Silky Flycatchers: Phainopepla

Shrikes, starlings: Loggerhead Shrike, European Starling

Vireos: Cassin's Vireo, Plumbeous Vireo, Yellow-throated Vireo, Hutton's Vireo, Warbling Vireo, Red-eyed Vireo

Wood Warblers: Tennessee Warbler, Orange-crowned Warbler, Nashville Warbler, Virginia's Warbler, Lucy's Warbler, Northern Parula, Yellow Warbler, Chestnut-sided Warbler, Magnolia Warbler, Yellow-rumped Warbler, Black-throated Gray Warbler, Black-throated Blue Warbler, Townsend's Warbler, Hermit Warbler, Black-throated Green Warbler, Blackburnian Warbler, Prairie Warbler, Palm Warbler, Blackpoll Warbler, Black \& White Warbler, American Redstart, Prothonotary Warbler, Wormeating Warbler, MacGillivray's Warbler, Dusky Warbler (fifth California sighting), Common Yellowthroat, Hooded Warbler, Canada Warbler, Wilson's Warbler, Yellowbreasted Chat

Tanagers: Summer Tanager, Western Tanager

Grosbeaks, buntings: Black-headed Grosbeak, Blue Grosbeak, Lazuli Bunting, Indigo Bunting 
Towhees, sparrows: Spotted Towhee, California Towhee, Chipping Sparrow, Claycolored Sparrow, Vesper Sparrow, Lark Sparrow, Sage Sparrow, Savannah Sparrow, Grasshopper Sparrow, Fox Sparrow, Song Sparrow, Lincoln's Sparrow, Swamp Sparrow, White-throated Sparrow, Golden-crowned Sparrow, White-crowned Sparrow, Dark-eyed Junco, Dickcissel, Lapland Longspur, Chestnut-collared Longspur

Blackbirds, orioles,etc.: Bobolink, Red-winged Blackbird, Tricolored Blackbird, Western Meadowlark, Yellow-headed Blackbird, Brewer's Blackbird, Great-tailed Grackle, Brown-headed Cowbird, Baltimore Oriole, Hooded Oriole, Bullock's Oriole, Orchard Oriole

Finches: Purple Finch, House Finch, Red Crossbill, Pine Siskin, Lesser Goldfinch, Lawrence's Goldfinch, American Goldfinch 


\section{APPENDIX B1: Results of 2001 Santa Maria Audubon Society Bird Count Conducted on VAFB (Source: National Audubon Society 2001)}

\begin{tabular}{|c|c|c|c|c|c|}
\hline $\begin{array}{l}\text { No. } \\
\text { Seen }\end{array}$ & Species & $\begin{array}{c}\text { No. } \\
\text { Seen }\end{array}$ & Species & $\begin{array}{c}\text { No. } \\
\text { Seen }\end{array}$ & Species \\
\hline 13 & Red-throated Loon & 2 & Virginia Rail & 43 & Western Scrub Jay \\
\hline 27 & Pacific Loon & 2 & Sora & 15 & American Crow \\
\hline 32 & Eared Grebe & 124 & Black-bellied Plover & 25 & Horned Lark \\
\hline 7 & Pied-billed Grebe & 2 & Semipalmated Plover & 50 & Tree Swallow \\
\hline 11 & Western Grebe & 31 & Snowy Plover & 5 & Oak Titmouse \\
\hline 19 & Brown Pelican & 110 & Killdeer & 34 & Chestnut-backed Chickadee \\
\hline 10 & Double-crested Cormorant & 1 & Black Oystercatcher & 157 & Bushtit \\
\hline 31 & Pelagic Cormorant & 7 & American Avocet & 35 & Bewick's Wren \\
\hline 1 & Brandt's Cormorant & 19 & Greater Yellowlegs & 2 & Marsh Wren \\
\hline 8 & Great Blue Heron & 1 & Spotted Sandpiper & 23 & Wrentit \\
\hline 4 & Great Egret & 16 & Long-billed Curlew & 10 & Golden-crowned Kinglet \\
\hline 1 & Snowy Egret & 4 & Marbled Godwit & 84 & Ruby-crowned Kinglet \\
\hline 2 & Green Heron & 1 & Black Turnstone & 19 & Blue-gray Gnatcatcher \\
\hline 3 & Black-crowned Night Heron & 3 & Surfbird & 6 & Mountain Bluebird \\
\hline 1 & White-faced Ibis & 530 & Sanderling & 4 & Western Bluebird \\
\hline 62 & Canada Goose & 58 & Dunlin & 2 & Hermit Thrush \\
\hline 1 & Brant & 210 & Western Sandpiper & 2 & Northern Mockingbird \\
\hline 39 & Ross's Goose & 340 & Least Sandpiper & 5 & California Thrasher \\
\hline 172 & Mallard & 64 & Long-billed Dowitcher & 4068 & European Starling \\
\hline 91 & Gadwall & 5 & Common Snipe & 332 & American Pipit \\
\hline 2 & Northern Pintail & 288 & Bonaparte's Gull & 4 & Orange-crowned Warbler \\
\hline 75 & American Wigeon & 390 & Mew Gull & 1 & Nashville Warbler \\
\hline 503 & Northern Shoveler & 10 & Ring-billed Gull & 121 & Yellow-rumped Warbler (form?) \\
\hline 17 & Cinnamon Teal & 135 & California Gull & 80 & Yellow-rumped Warbler (Audubon's) \\
\hline 151 & Am Green-winged Teal & 53 & Herring Gull & 3 & Yellow-rumped Warbler (Myrtle) \\
\hline 61 & Canvasback & 2 & Thayer's Gull & 10 & Townsend's Warbler \\
\hline 1 & Redhead & 27 & Glaucous-winged Gull & 21 & Common Yellowthroat \\
\hline 37 & Ring-necked Duck & 125 & Western Gull & 1 & Wilson's Warbler \\
\hline
\end{tabular}




\begin{tabular}{|c|c|c|c|c|c|}
\hline $\begin{array}{l}\text { No. } \\
\text { Seen }\end{array}$ & Species & $\begin{array}{c}\text { No. } \\
\text { Seen }\end{array}$ & Species & $\begin{array}{l}\text { No. } \\
\text { Seen }\end{array}$ & Species \\
\hline 1 & Lesser Scaup & 9 & Heermann's Gull & 19 & Spotted Towhee \\
\hline 19 & Surf Scoter & 15 & Royal Tern & 19 & California Towhee \\
\hline 7 & Bufflehead & 4 & Mourning Dove & 35 & Savannah Sparrow (form?) \\
\hline 313 & Ruddy Duck & 22 & Rock Dove & 13 & Golden-crowned Sparrow \\
\hline 58 & Turkey Vulture & 1 & Greater Roadrunner & 1 & White-throated Sparrow \\
\hline 20 & Northern Harrier & 4 & Great Horned Owl & 268 & White-crowned Sparrow \\
\hline 13 & White-tailed Kite & 2 & Burrowing Owl & 52 & Song Sparrow \\
\hline 1 & Sharp-shinned Hawk & 2 & Western Screech Owl & 1 & Lincoln's Sparrow \\
\hline 2 & Cooper's Hawk & 26 & Anna's Hummingbird & 8 & Dark-eyed (Oregon) Junco \\
\hline 5 & Red-shouldered Hawk & 1 & Belted Kingfisher & 358 & Western Meadowlark \\
\hline 65 & Red-tailed Hawk & 6 & Downy Woodpecker & 2 & Brown-headed Cowbird \\
\hline 3 & Ferruginous Hawk & 12 & Nuttall's Woodpecker & 2 & Tricolored Blackbird \\
\hline 1 & Golden Eagle & 24 & Northern Flicker & 952 & Red-winged Blackbird \\
\hline 1 & Merlin & 55 & Black Phoebe & 739 & Brewer's Blackbird \\
\hline 42 & American Kestrel & 51 & Say's Phoebe & 736 & House Finch \\
\hline 2 & Peregrine Falcon & 2 & Cassin's Kingbird & 5 & Lesser Goldfinch \\
\hline 53 & California Quail & 22 & Loggerhead Shrike & 2 & American Goldfinch \\
\hline 513 & American Coot & 2 & Hutton's Vireo & 30 & House Sparrow \\
\hline
\end{tabular}


APPENDIX B2: Results of 2001 La Purisima Audubon Society Bird Count
Conducted on VAFB (Source: La Purisima Audubon Society 2002)

\begin{tabular}{|c|c|c|c|c|c|}
\hline $\begin{array}{c}\text { No. } \\
\text { Seen }\end{array}$ & Species & $\begin{array}{c}\text { No. } \\
\text { Seen }\end{array}$ & Species & $\begin{array}{c}\text { No. } \\
\text { Seen }\end{array}$ & Species \\
\hline 15 & Red-throated Loon & 17 & Oak Titmouse & 1 & Chipping Sparrow \\
\hline 180 & Pacific Loon & 1 & White-breasted Nuthatch & 1 & Lark Sparrow \\
\hline 8 & Common Loon & 7 & Red-breasted Nuthatch & 1 & Sage Sparrow \\
\hline 20 & Pied-billed Grebe & 29 & Bewick's Wren & 22 & Savannah Sparrow (form?) \\
\hline 16 & Eared Grebe & 6 & House Wren & 3 & Fox Sparrow \\
\hline 15 & Western Grebe & 9 & Marsh Wren & 103 & Song Sparrow \\
\hline 1 & Pink Footed Shearwater & 68 & Bufflehead & 6 & Lincoln's Sparrow \\
\hline 15 & Black-vented Shearwater & 1 & Hooded Merganser & 2 & White-throated Sparrow \\
\hline 22 & Brown Pelican & 189 & Ruddy Duck & 274 & White-crowned Sparrow \\
\hline 30 & Double-crested Cormorant & 3 & White-tailed Kite & 74 & Golden-crowned Sparrow \\
\hline 5 & Brandt's Cormorant & 16 & Northern Harrier & 62 & Dark-eyed (Oregon) Junco \\
\hline 11 & Pelagic Cormorant & 4 & Sharp-shinned Hawk & 154 & Killdeer \\
\hline 26 & Great Blue Heron & 7 & Cooper's Hawk & 11 & Mountain Plover \\
\hline 5 & Great Egret & 9 & Red-shouldered Hawk & 4 & Black Oystercatcher \\
\hline 25 & Snowy Egret & 46 & Red-tailed Hawk & 10 & Black-necked Stilt \\
\hline 23 & Black-crowned Night Heron & 8 & Ferruginous Hawk & 18 & Greater Yellowlegs \\
\hline 59 & Turkey Vulture & 5 & Golden Eagle & 1 & Wandering Tattler \\
\hline 240 & Canada Goose & 61 & American Kestrel & 2 & Spotted Sandpiper \\
\hline 1 & Greater White-fronted Goose & 1 & Peregrine Falcon & 1 & Long-billed Curlew \\
\hline 2 & Snow Goose & 1 & Prairie Falcon & 3 & Ruddy Turnstone \\
\hline 3 & Ross's Goose & 2 & Wild Turkey & 27 & Black Turnstone \\
\hline 13 & American Wigeon & 127 & California Quail & 12 & Surfbird \\
\hline 33 & Gadwall & 2 & Virginia Rail & 59 & Sanderling \\
\hline 36 & Green-winged Teal & 7 & Sora & 60 & Western Sandpiper \\
\hline 418 & Mallard & 1 & Common Moorhen & 192 & Least Sandpiper \\
\hline 148 & Northern Pintail & 544 & American Coot & 24 & Long-billed Dowitcher \\
\hline 6 & Cinnamon Teal & 134 & Black-bellied Plover & 5 & Common Snipe \\
\hline 169 & Northern Shoveler & 30 & Snowy Plover & 2 & Parasitic Jaeger \\
\hline 3 & Canvasback & 20 & Golden-crowned Kinglet & 6 & Bonaparte's Gull \\
\hline
\end{tabular}




\begin{tabular}{|c|c|c|c|c|c|}
\hline $\begin{array}{l}\text { No. } \\
\text { Seen }\end{array}$ & Species & $\begin{array}{l}\text { No. } \\
\text { Seen }\end{array}$ & Species & $\begin{array}{l}\text { No. } \\
\text { Seen }\end{array}$ & Species \\
\hline 4 & Redhead & 125 & Ruby-crowned Kinglet & 11 & Heermann's Gull \\
\hline 42 & Ring-necked Duck & 15 & Blue-gray Gnatcatcher & 146 & Mew Gull \\
\hline 284 & Surf Scoter & 29 & Western Bluebird & 110 & Ring-billed Gull \\
\hline 18 & White-winged Scoter & 25 & Hermit Thrush & 86 & California Gull \\
\hline 3 & Western Screech Owl & 32 & American Robin & 95 & Herring Gull \\
\hline 10 & Great Horned Owl & 102 & Wrentit & 1 & Thayer's Gull \\
\hline 1 & Northern Pygmy Owl & 9 & Northern Mockingbird & 137 & Western Gull \\
\hline 8 & Burrowing Owl & 10 & California Thrasher & 11 & Glaucous-winged Gull \\
\hline 4 & Short-eared Owl & 309 & American Pipit & 4 & Royal Tern \\
\hline 17 & White-throated Swift & 3 & Cedar Waxwing & 8 & Pigeon Guillemot \\
\hline 44 & Anna's Hummingbird & 10 & Loggerhead Shrike & 71 & Rock Dove \\
\hline 10 & Acorn Woodpecker & 250 & European Starling & 30 & Mourning Dove \\
\hline 21 & Nuttall's Woodpecker & 18 & Hutton's Vireo & 60 & Band-tailed Pigeon \\
\hline 12 & Downy Woodpecker & 1 & Golden-winged Warbler & 37 & Euroasian Collard-Dove \\
\hline 8 & Hairy Woodpecker & 3 & Orange-crowned Warbler & 2 & Greater Roadrunner \\
\hline 57 & Northern (Red-shafted) Flicker & 130 & Yellow-rumped Warbler (form?) & & Barn Owl \\
\hline 49 & Black Phoebe & 141 & $\begin{array}{l}\text { Yellow-rumped Warbler } \\
\text { (Audubon's) }\end{array}$ & 5 & Brown-headed Cowbird \\
\hline 55 & Say's Phoebe & 52 & Yellow-rumped Warbler (Myrtle) & 448 & Western Meadowlark \\
\hline 1 & Cassin's Kingbird & 13 & Townsend's Warbler & 379 & Red-winged Blackbird \\
\hline 265 & Tree Swallow & 1 & Hermit Warbler & 21 & Tricolored Blackbird \\
\hline 180 & Horned Lark & 44 & Common Yellowthroat & 321 & Brewer's Blackbird \\
\hline 1 & Barn Swallow & 2 & Wilson's Warbler & 51 & Purple Finch \\
\hline 87 & Western Scrub Jay & 32 & Spotted Towhee & 711 & House Finch \\
\hline 399 & American Crow & 47 & California Towhee & 4 & Pine Siskin \\
\hline \multirow[t]{3}{*}{21} & Chestnut-backed Chickadee & 4 & Rufous-crowned Sparrow & 31 & Lesser Goldfinch \\
\hline & & & & 17 & American Goldfinch \\
\hline & & & & 43 & House Sparrow \\
\hline
\end{tabular}




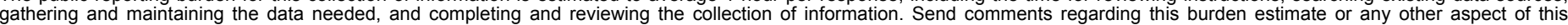

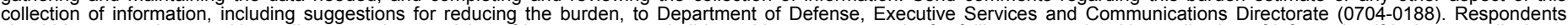

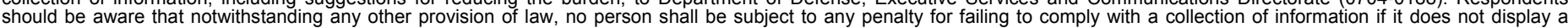
surrently alid OMB

PLEASE DO NOT RETURN YOUR FORM TO THE ABOVE ORGANIZATION.

\section{REPORT DATE (DD-MM-YYYY) August 2004 \\ 2. REPORT TYPE \\ Subcontractor Report}

4. TITLE AND SUBTITLE

A Preliminary Assessment of Potential Avian Interactions at Four Proposed Wind Energy Facilities on Vandenberg Air Force Base, California

Four
Base,

3. DATES COVERED (From - To)

November 2001 - May 2002

5a. CONTRACT NUMBER

DE-AC36-99-GO10337

5b. GRANT NUMBER
6. AUTHOR(S)

BioResource Consultants 5d. PROJECT NUMBER

NREL/SR-500-34961

\section{5e. TASK NUMBER}

WER4 7202

5f. WORK UNIT NUMBER

\section{PERFORMING ORGANIZATION NAME(S) AND ADDRESS(ES) \\ BioResource Consultants \\ PO Box 1539 \\ Ojai, California 93024}

\section{PERFORMING ORGANIZATION REPORT NUMBER \\ LAT-1-31237-01}

9. SPONSORING/MONITORING AGENCY NAME(S) AND ADDRESS(ES)

National Renewable Energy Laboratory

1617 Cole Blvd.

10. SPONSOR/MONITOR'S ACRONYM(S) NREL

Golden, CO 80401-3393

11. SPONSORING/MONITORING AGENCY REPORT NUMBER NREL/SR-500-34961

\section{DISTRIBUTION AVAILABILITY STATEMENT}

National Technical Information Service

U.S. Department of Commerce

5285 Port Royal Road

Springfield, VA 22161

13. SUPPLEMENTARY NOTES

NREL Technical Monitor: K. Sinclair

14. ABSTRACT (Maximum 200 Words)

The United States Air Force (USAF) is investigating whether to install wind turbines to provide a supplemental source of electricity at Vandenberg Air Force Base (VAFB) near Lompoc, California. As part of that investigation, VAFB sought assistance from the U.S. Department of Energy's National Renewable Energy Laboratory (NREL) to provide a preliminary characterization of the potential risk to wildlife resources (mainly birds and bats) from wind turbine installations. With wind power development expanding throughout North America and Europe, concerns have surfaced over the number of bird fatalities associated with wind turbines. Guidelines developed for the wind industry by the National Wind Coordinating Committee (NWCC) recommend assessing potential impacts to birds, bats, and other potentially sensitive resources before construction. The primary purpose of an assessment is to identify potential conflicts with sensitive resources, to assist developers with identifying their permitting needs, and to develop strategies to avoid impacts or to mitigate their effects. This report provides a preliminary (Phase I) biological assessment of potential impacts to birds and bats that might result from construction and operation of the proposed wind energy facilities on VAFB.

\section{SUBJECT TERMS}

wind energy; wind turbine; Vandenberg Air Force Base; avian; bird fatalities

\begin{tabular}{|c|c|c|c|c|}
\hline \multicolumn{3}{|c|}{ 16. SECURITY CLASSIFICATION OF: } & \multirow{2}{*}{$\begin{array}{l}\text { 17. LIMITATION } \\
\text { OF ABSTRACT } \\
\text { UL }\end{array}$} & \multirow{2}{*}{$\begin{array}{l}\text { 18. NUMBER } \\
\text { OF PAGES }\end{array}$} \\
\hline $\begin{array}{l}\text { a. REPORT } \\
\text { Unclassified }\end{array}$ & $\begin{array}{l}\text { b. ABSTRACT } \\
\text { Unclassified }\end{array}$ & $\begin{array}{l}\text { c. THIS PAGE } \\
\text { Unclassified }\end{array}$ & & \\
\hline
\end{tabular}

19b. TELEPONE NUMBER (Include area code) 